\title{
RESEARCH
}

Open Access

\section{Yao herbal medicinal market during the Dragon Boat Festival in Jianghua County, China}

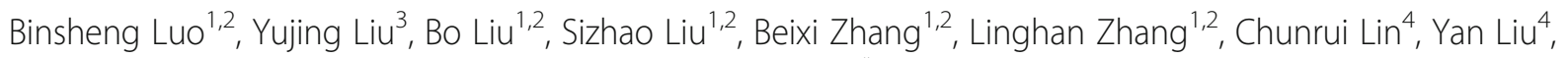
Edward J. Kennelly, 2, Zhiyong Guo ${ }^{1,2}$ and Chunlin Long ${ }^{1,2,6^{*}}$ (D)

\begin{abstract}
Background: The traditional medicinal markets held during the Dragon Boat Festival are common and important in China's countryside. In Jianghua, a Yao autonomous county in Hunan Province in China, the medicinal market also plays an important role for the application, conservation, and communication of traditional Yao medicinal knowledge.

Methods: During the Dragon Boat Festival in 2016 and 2017, ethnobotanical surveys and inventories were conducted in the medicinal market of Jianghua County, and voucher plant specimens were collected, identified, and deposited in a herbarium. Quantitative analysis included measurement of frequency of occurrence for species in the marketplace and the relative importance index for the number of uses for a given species.

Results: A total of 306 plant species (249 genera, 113 families) and their related information about the medicinal market were collected. Some major findings include the following: (1) Using the whole plant as medicine is more common than other medicinal plant parts; (2) treating rheumatism and clearing inner heat are the most frequent medicinal uses; and (3) taking a medicinal bath is the most frequent modality to administer the traditional medicine. The frequency of occurrence and the relative importance index of some medicinal plants were analyzed, as well as the demographics and the number of stalls and the status of traditional Yao medicinal knowledge in Jianghua. Based on the investigation, suggestions were proposed for better protecting the medicinal market and preserving traditional medicinal knowledge in Jianghua County.
\end{abstract}

Conclusion: The medicinal market during the Dragon Boat Festival in Jianghua County possesses an important cultural value and helps to conserve the traditional Yao medicinal knowledge. The medicinal plants sold at the market showed great diversity and unique local characteristics. The medicinal market is facing some challenges in such a rapidly developing era. Cultivation of young healers and maintaining the local biodiversity might be the key solutions for the development of local medicinal market and local Yao medicinal knowledge.

Keywords: Dragon Boat Festival, Yao ethnic group, Jianghua County, Traditional knowledge, Conservation

\footnotetext{
*Correspondence: long@mail.kib.ac.cn; long.chunlin@muc.edu.cn

'Key Laboratory of Ethnomedicine (Minzu University of China), Ministry of

Education, Beijing 100081, China

${ }^{2}$ College of Life and Environmental Sciences, Minzu University of China,

Beijing 100081, China

Full list of author information is available at the end of the article
}

(c) The Author(s). 2018 Open Access This article is distributed under the terms of the Creative Commons Attribution 4.0 International License (http://creativecommons.org/licenses/by/4.0/), which permits unrestricted use, distribution, and reproduction in any medium, provided you give appropriate credit to the original author(s) and the source, provide a link to the Creative Commons license, and indicate if changes were made. The Creative Commons Public Domain Dedication waiver (http://creativecommons.org/publicdomain/zero/1.0/) applies to the data made available in this article, unless otherwise stated. 


\section{Background}

The Dragon Boat Festival, occurring on the fifth day of the fifth month in the Chinese lunar calendar, is one of the most famous traditional festivals in China. People eat zongzi (a special food made from sticky rice and other ingredients), drink realgar wine, and race dragon boats to celebrate this festival all over the country. However, in Jianghua, a county with the largest population of Yao people in China [1], the Dragon Boat Festival is a special opportunity for the local people to trade medicinal plants in a large market. It has become the most important tradition in Jianghua. During this festival, the Yao villagers bring medicinal plants collected recently to the market. They share and exchange the experiences of identifying, harvesting, and applying their medicinal plants with each other and with consumers. This unique medicinal market has already become a great platform for different people to communicate with and learn from each other [2]. This spontaneous traditional activity is also making vital contributions to the sustainable conservation, transmission, and expansion of related traditional knowledge [3].

The Yao is an ancient ethnic group, and one of the 55 officially recognized minority groups of the Chinese government. The largest populations of Yao live in the mountains and high ranges of southern China and practice slash-and-burn agriculture and hunt $[4,5]$. Based on the long-term practice, the Yao people depend on local plant resources to prevent and treat diseases. They have developed their own traditional medicine system, as well as distinct customs to promote health. For example, they use Acorus calamus, Artemisia argyi, and realgar to keep pests and pathogens away [4]. Our previous investigation (unpublished) indicated that in traditional culture of the Yao ethnic group, the Dragon Boat Festival is believed to be the birthday of the so-called Medicinal Lord. The effect of medicinal plants during this festival is believed to be the best by local people. Thus, the medicinal market has become the biggest and the most popular event on the Dragon Boat Festival in Jianghua.

In recent years, more scientists have studied natural herbal medicine to determine their efficacy and potentially develop validated new drugs and health care products [5, 6]. As a natural treasury of traditional medicinal knowledge, the markets selling herbal drugs possess great potential for new drug discovery [7]. Using the Web of Science with search term "medicinal market and China", only four English-language research papers can be found [8-11].

As a cultural phenomenon in China, several Chinese-language papers have reported different medicinal markets during the Dragon Boat Festival, such as the investigations in Jingxi County [2, 12], Yongzhou City [13], and Gongcheng County [14]. These studies showed the species diversity of medicinal plants and their medicinal parts, medicinal purposes, modalities, and other information [2, 12-14].
Much of the traditional knowledge is in danger of being lost, so these local medicinal plant resources need to be protected [2, 12-14]. In Jianghua, the medicinal market in the Dragon Boat Festival is relatively large in scale, but very little scientific research has been carried out $[15,16]$.

Nowadays, as much traditional knowledge is in danger of disappearing, the traditional knowledge associated with the Jianghua medicinal marketplace should be preserved. Therefore, an ethnobotanical research focused on Jianghua medicinal market was conducted at the Dragon Boat Festival in 2016 and 2017. This study evaluates the status of the Jianghua medicinal market and analyzes the relationship among this medicinal market, local community, and local natural environment. Based on the study results, some suggestions are included for local communities to protect this medicinal market. Furthermore, this study may provide valuable clues for future development and also give comprehensive and scientific guidance for local people to consume the medicinal herbs in a safer manner.

\section{Methods \\ Study site}

Jianghua Yao Autonomous County belongs to Hunan Province and is located close to the border area of Guangdong Province, Guangxi Region, and Hunan Province in South China (Fig. 1). This area has a rich biodiversity, plentiful rainfall, and a mild temperature due to the low-latitude subtropical monsoon climate [17]. The population of Jianghua County is predominated by Yao people who account for more than half of the county's population. Other ethnic groups like Zhuang, Han, and Miao also live there but have smaller populations [17]. Our previous investigation showed that the medicinal market distributes on Changzhen Street and its branches. The market starts 2 days before the Dragon Boat Festival and it grows to its largest on the festival day.

\section{Ethnobotanical data collection and statistical analysis}

An ethnobotanical method was mainly used for this study. At the local market, each stall and vendor was investigated, and relevant information was recorded for all of the medicinal plants in trade. The chosen informants were vendors, buyers, and folk healers as well as other old knowledgeable people. Key informant interview was comprised of semistructured interview and free listing based on the informant consensus. By means of different interview methods, comprehensive information about the medicinal plants in the market for further analysis was obtained.

Quantitative analysis was used to reveal the taxonomic characters and diversity of the modalities, using parts and medicinal uses of the medicinal herbs. The medicinal market opened around the Dragon Boat Festival which is only about 3 days each year. We intensively collected information from the medicinal market (269 stalls), and the 


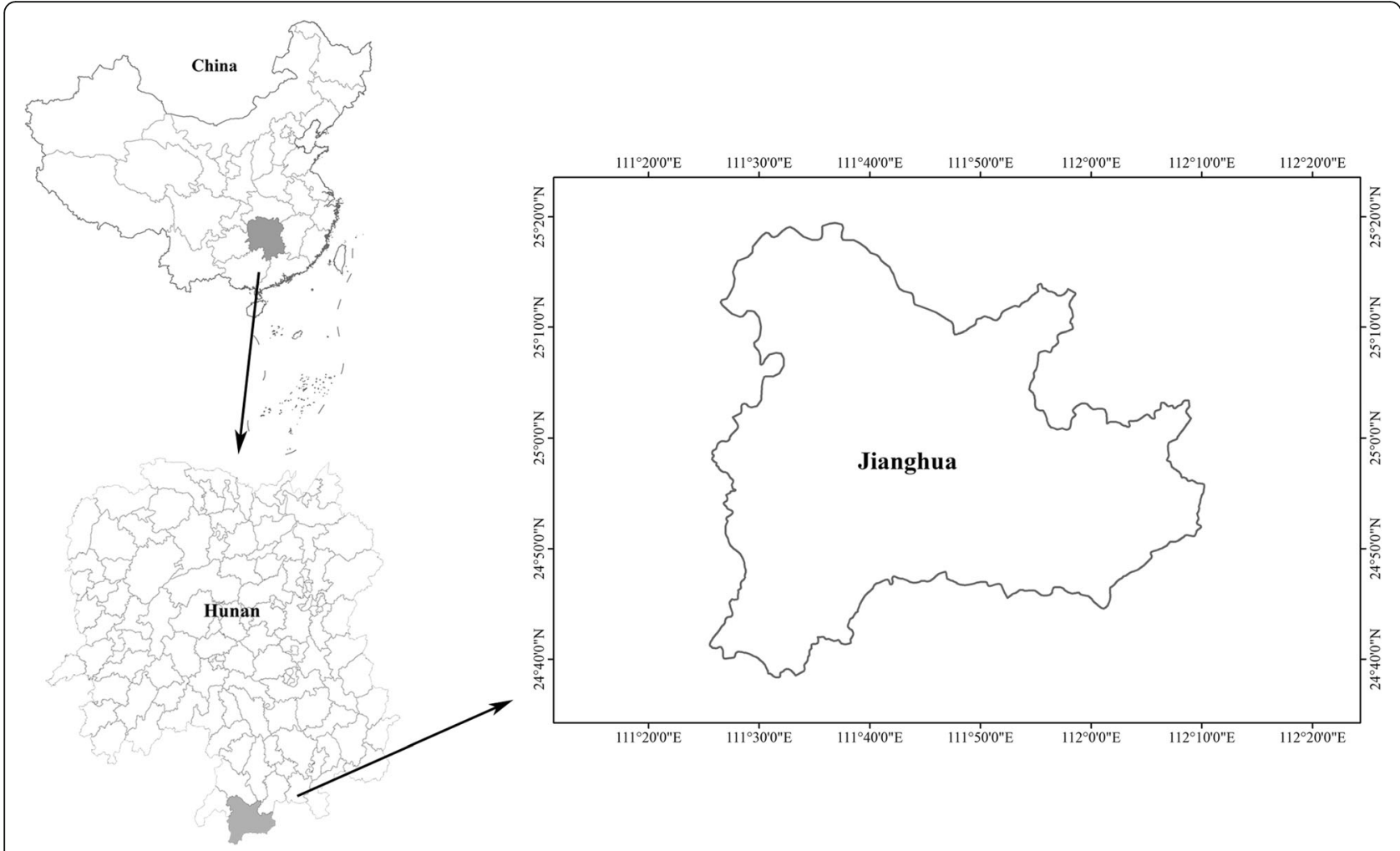

Fig. 1 The location of Jianghua County, Hunan Province, China

methods including pairwise comparison and rank ordering are almost impossible even they are much more robust. Instead, the frequency of the occurrence and the relative importance (RI) index of the medicinal herbs were employed.

RI was originally proposed by Bennet et al. in 2000 [18]. This index is used to evaluate the degree of development and utilization of certain plant species. The formula of RI is as below [19]:

$$
\mathrm{RI}=\mathrm{NUT}+\mathrm{NT}
$$

NUT is the number of categories used for a certain species divided by the number of all categories, and NT is the number of types of uses of a specific species divided by the number of all use types. During this study, NUT was equated as the number of types of therapeutic modalities (NM) of a given species divided by the number of all modalities [19]. Thus, RI is the sum of the NM and NT as the following formula:

$$
\mathrm{RI}=\mathrm{NM}+\mathrm{NT}
$$

The number of the vendors, the gender, and the age composition of the vendors were also analyzed.

Voucher specimens of medicinal plants were collected with assistance from the local people in the market, villages nearby, and local ecosystems. They were identified by botanical experts, Profs. Chunlin Long, Chunrui Lin, and Yan
Liu and Dr. Bo Liu. All specimens of medicinal plants collected in Jianghua were deposited in the College of Life and Environmental Sciences, Minzu University of China. The information compiled includes the following: vernacular names, scientific names, taxonomic status, using parts, medicinal uses, modalities, and voucher numbers of all medicinal plants collected in Jianghua. All the medicinal plants and related information are shown in Table 1.

\section{Results and discussion}

Diversity and characteristics of medicinal plants

By conducting field surveys at the Dragon Boat Festival marketplace in Jianghua in 2016 and 2017, 306 species belonging to 249 genera and 113 families were recorded and identified (Table 1). The taxonomic statistics clearly demonstrate the plant species biodiversity present in this Yao community market. The plant family with the most species represented was Asteraceae (23 species). Fabaceae (Leguminosae) was the second most common plant family with 15 species while Primulaceae and Lamiaceae were the third and fourth largest plant families with 11 and 10 species, respectively. Regarding plant genera, most of genera had three or fewer species represented, except for the genera Artemisia and Ardisia (Table 1). Seven species of Ardisia were found in the marketplace, while five species of Artemisia were present. The genus Ardisia, which contains a large number of medicinal species, has more than 


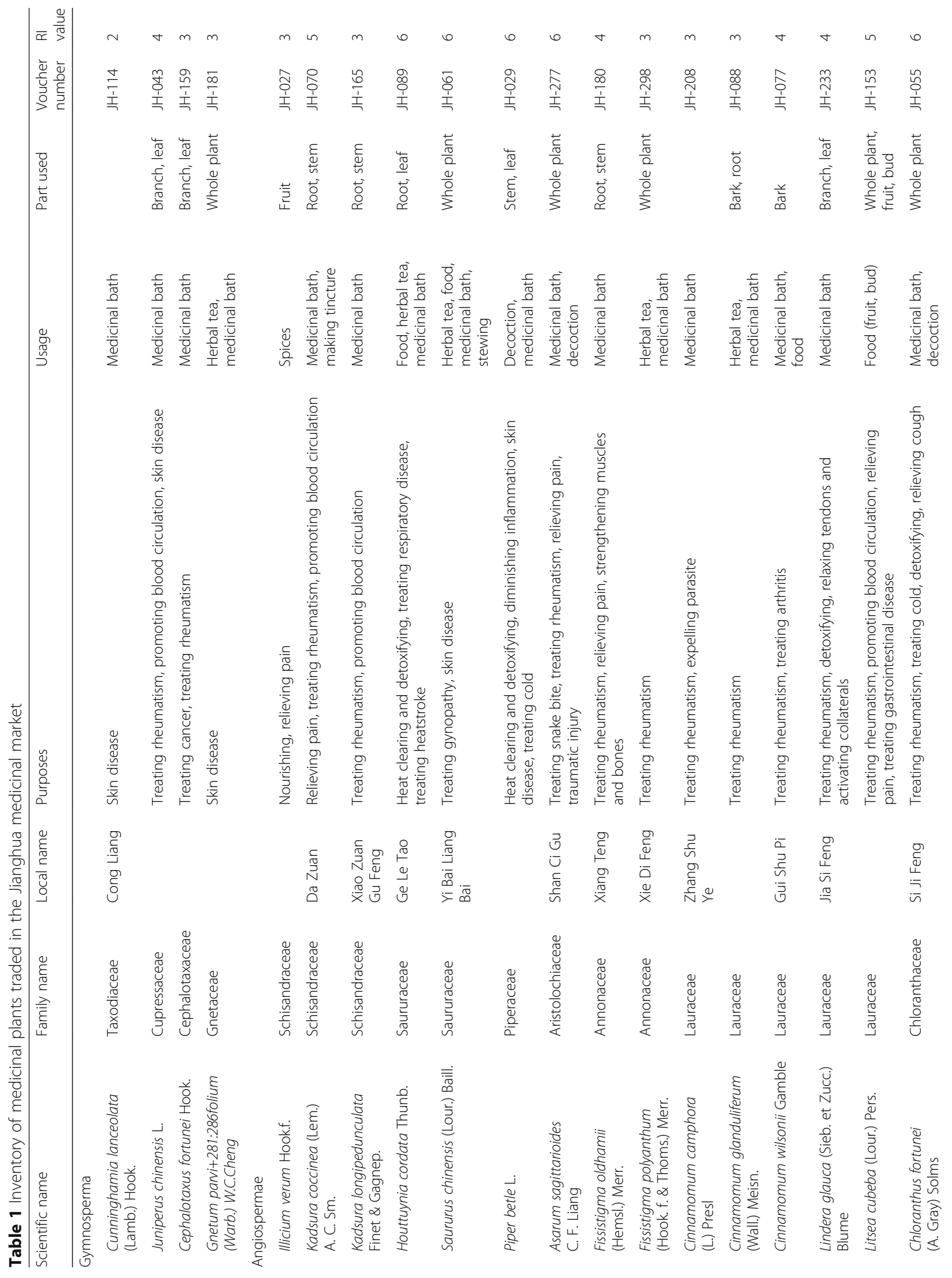




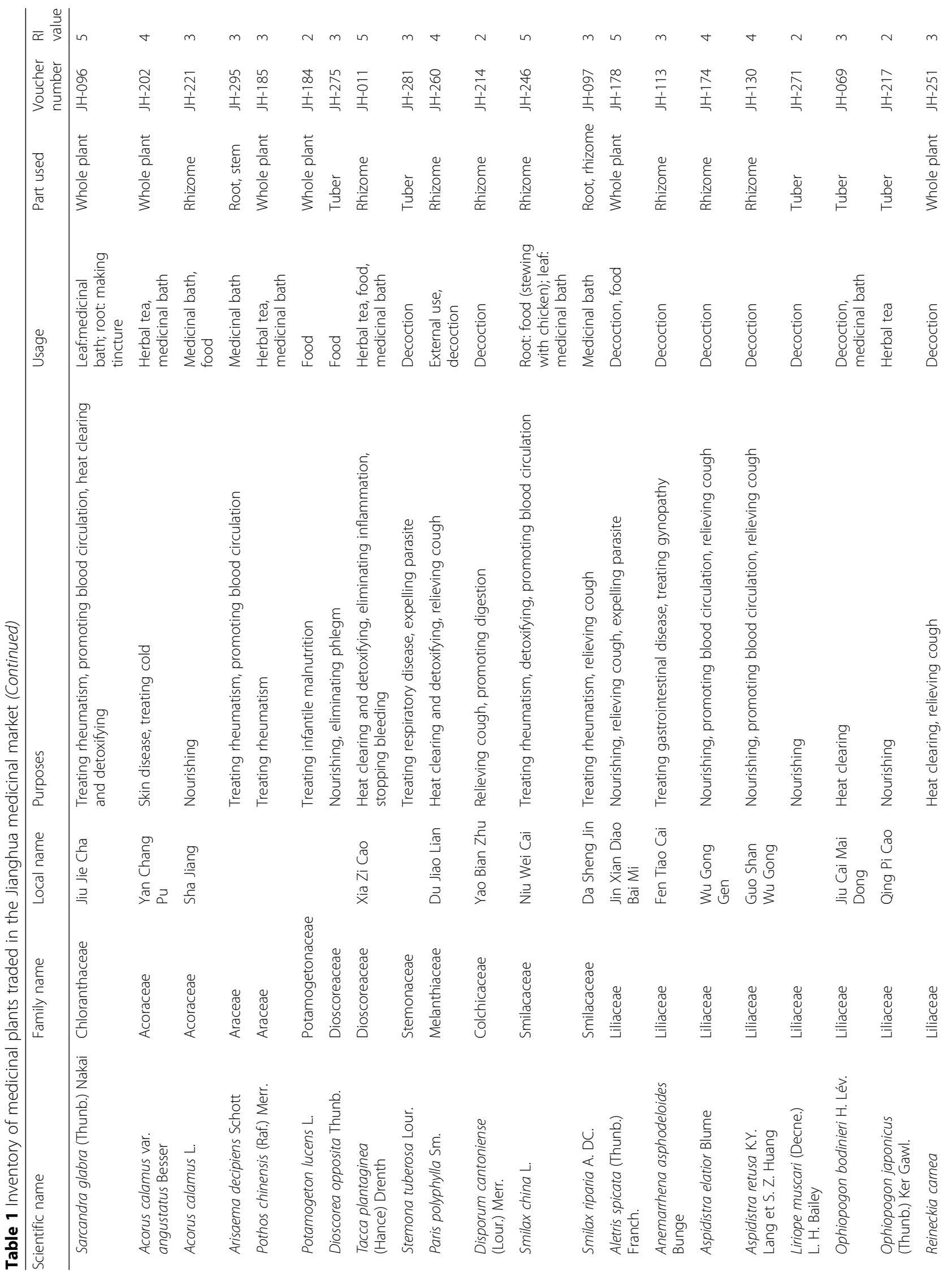




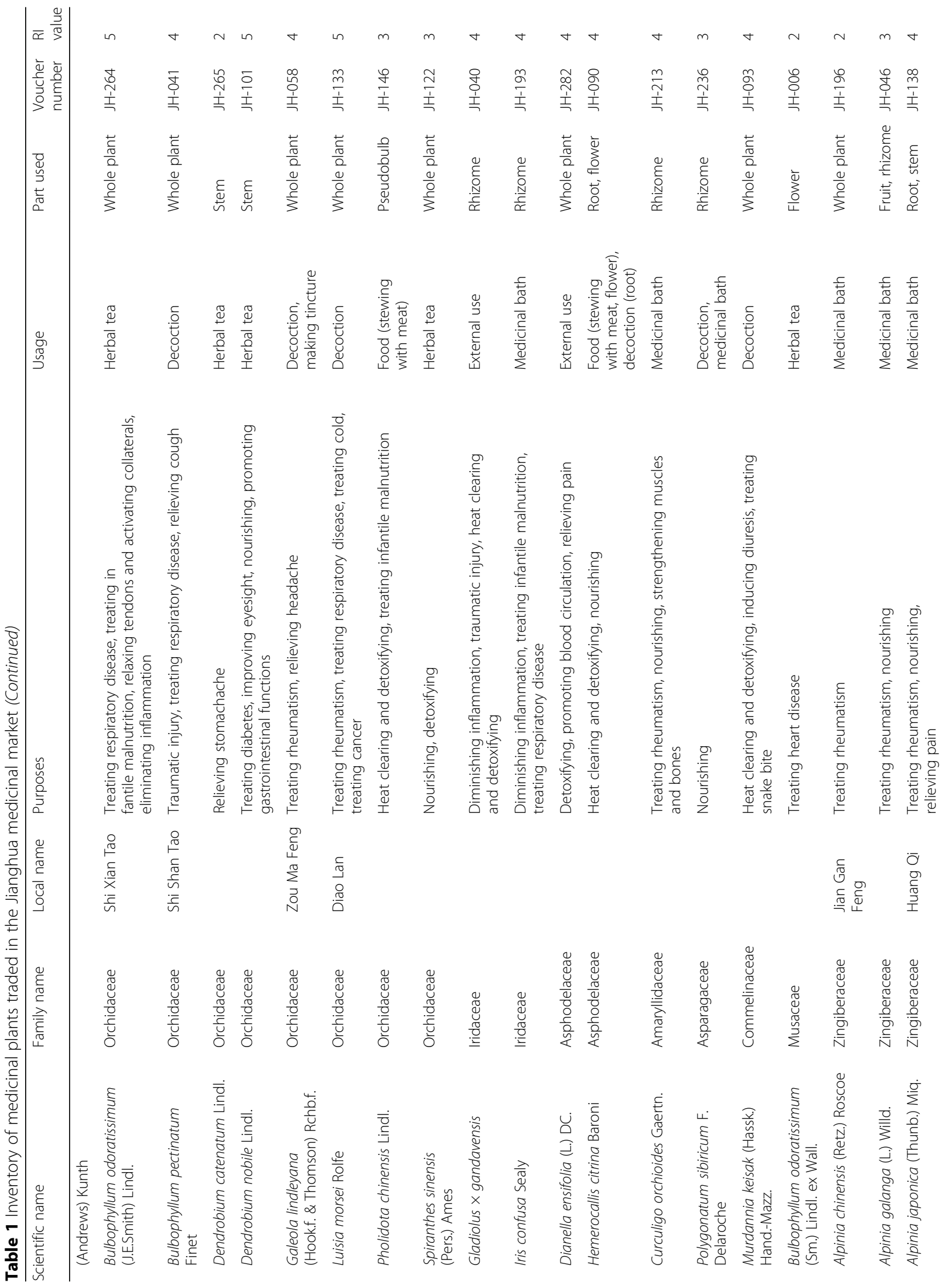




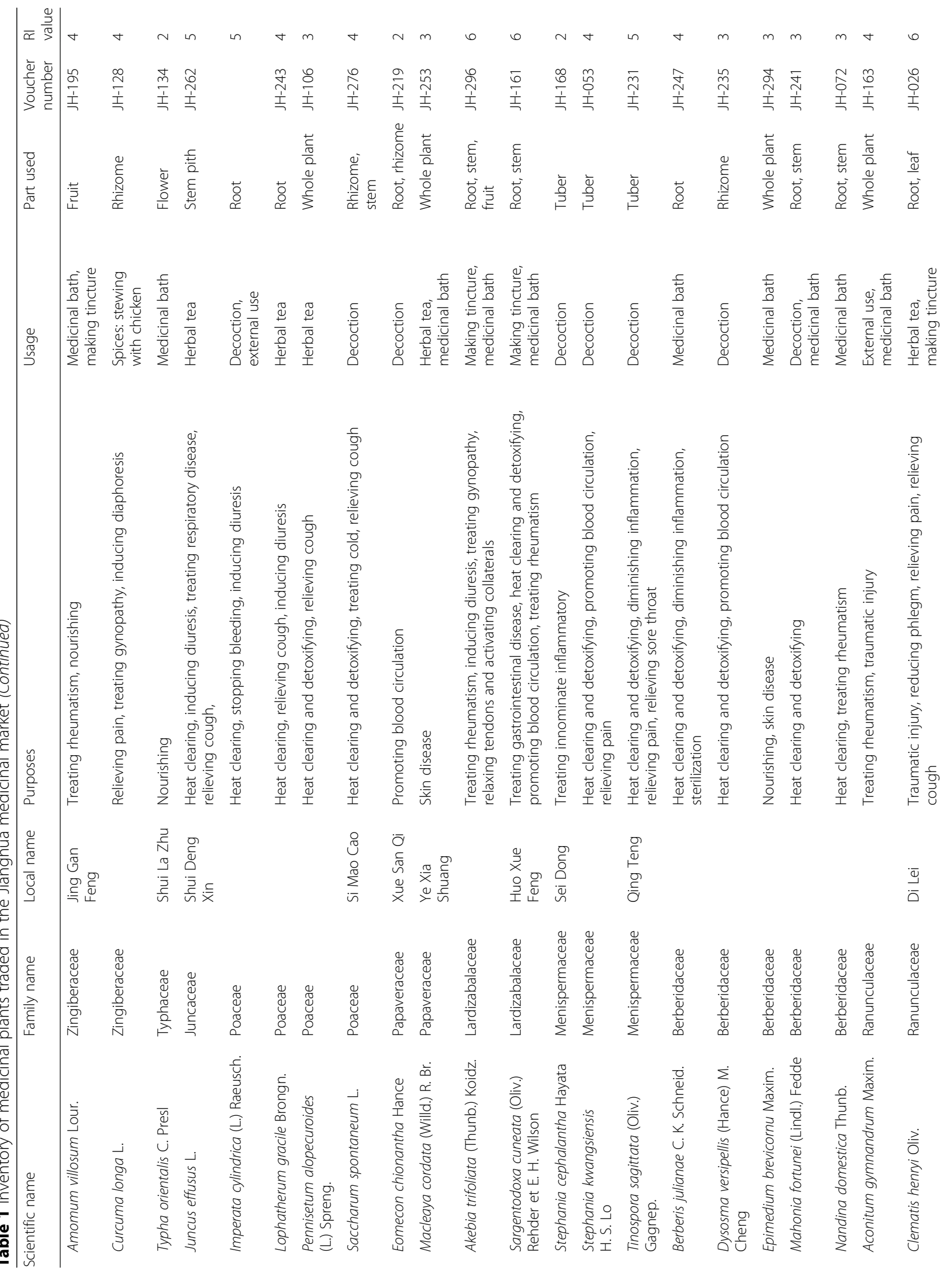




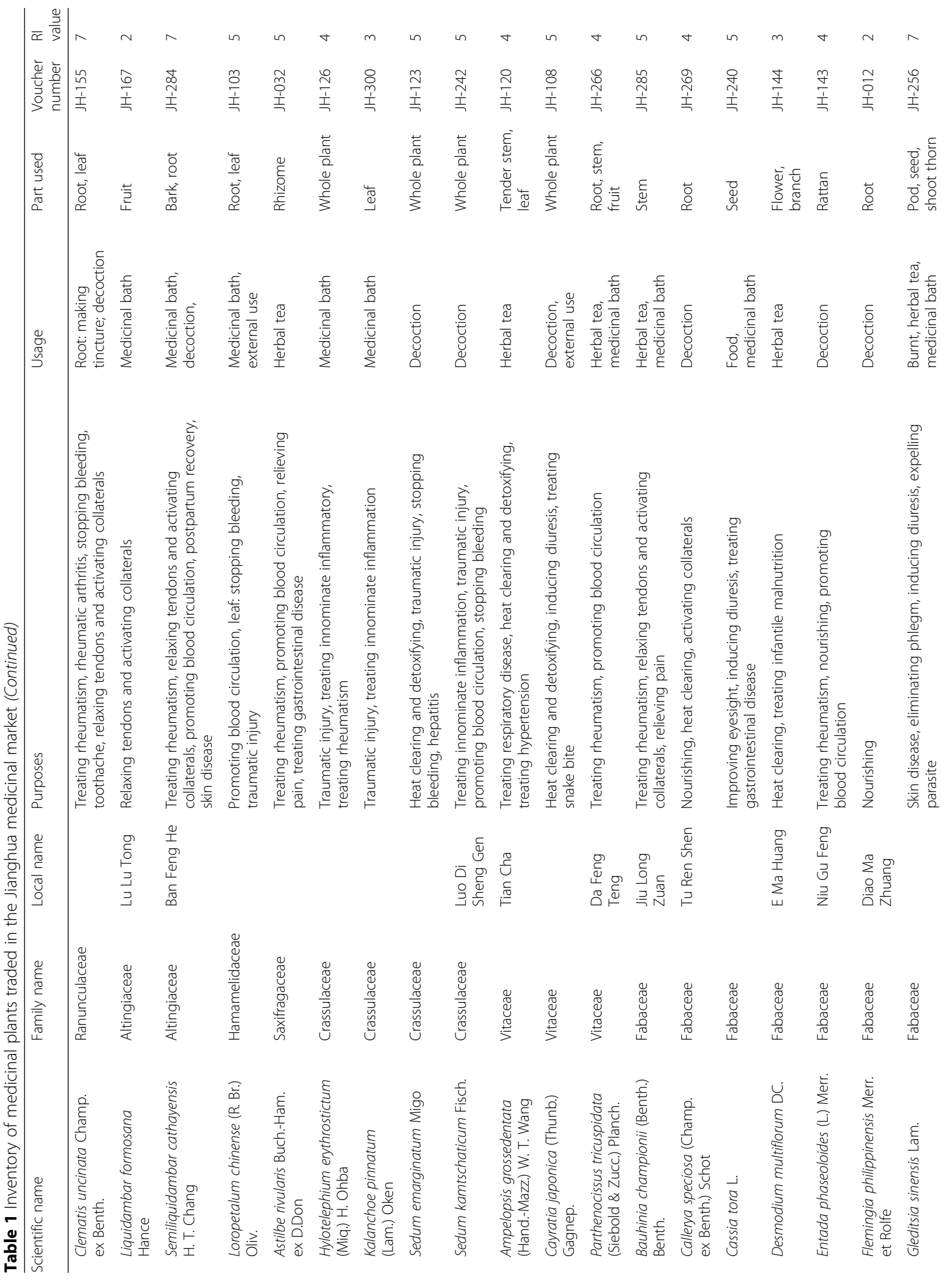




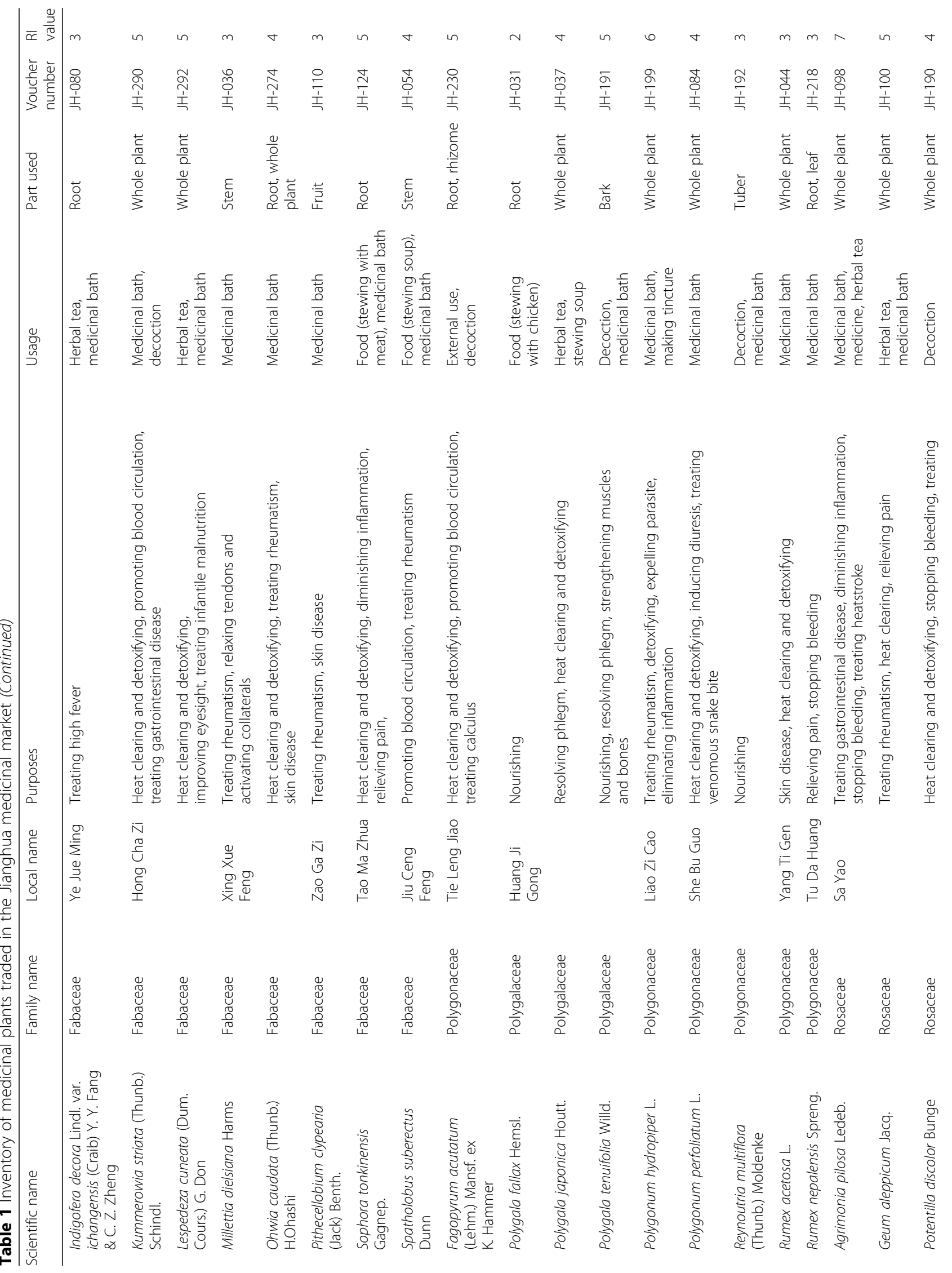




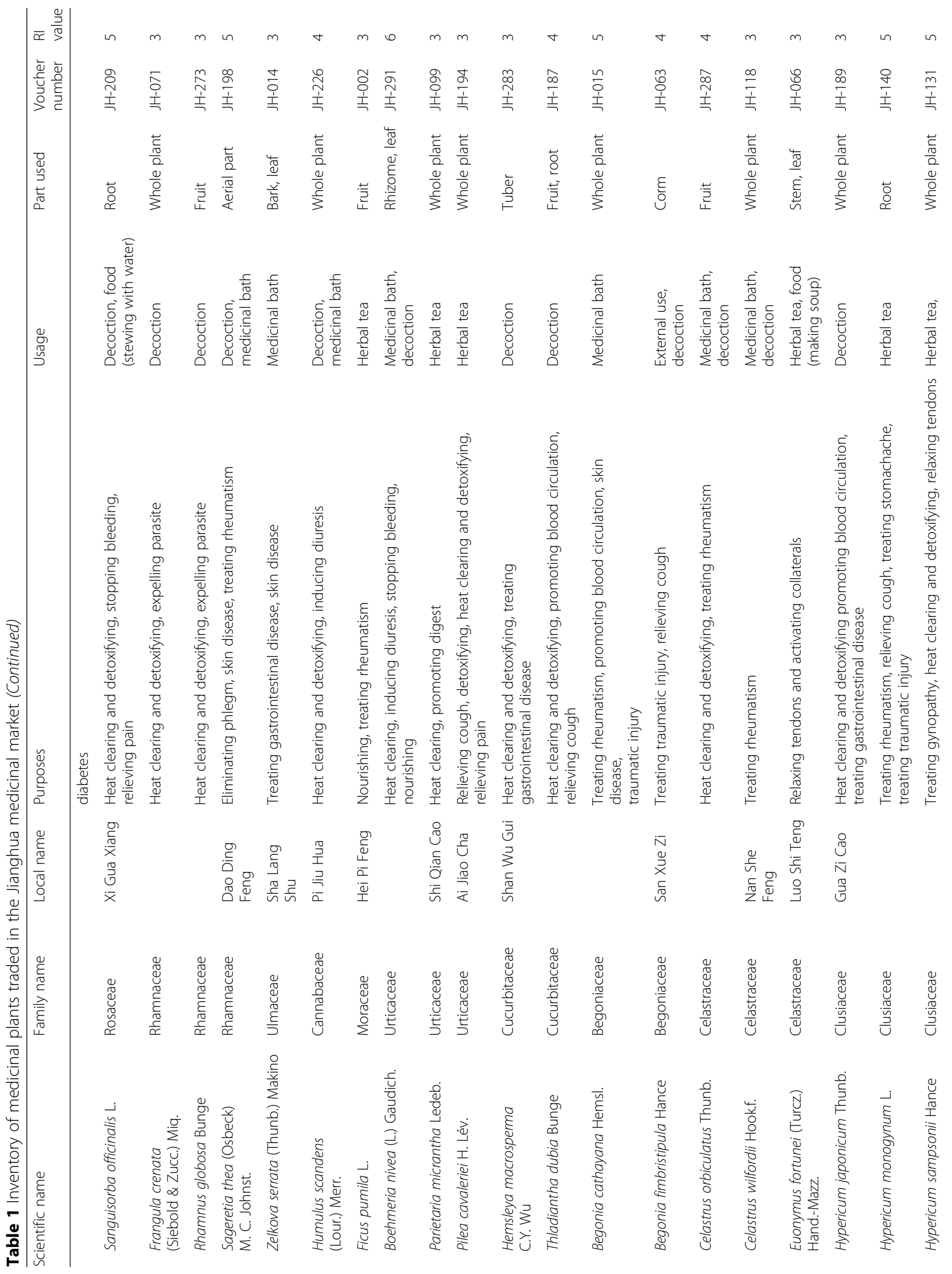




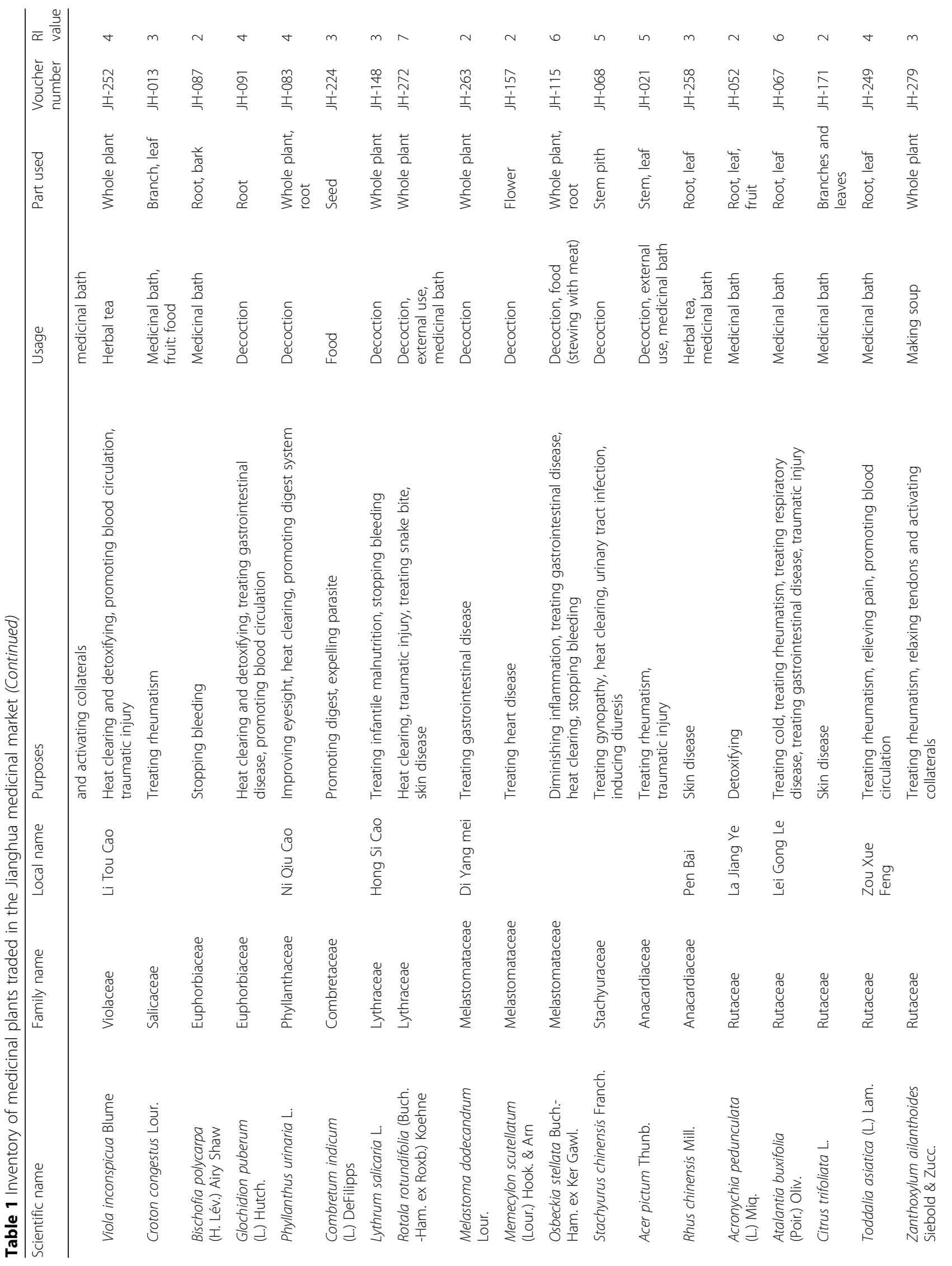




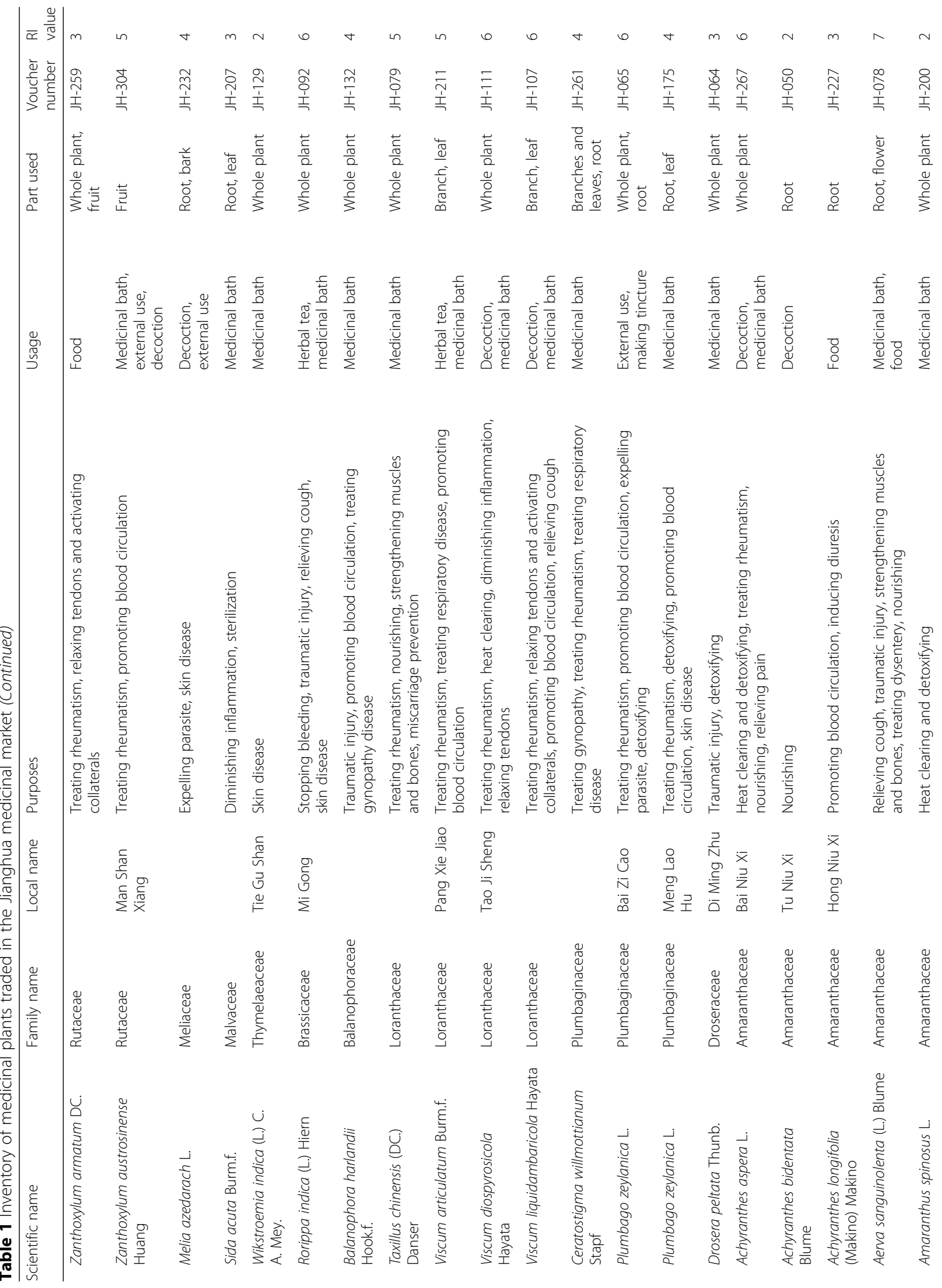




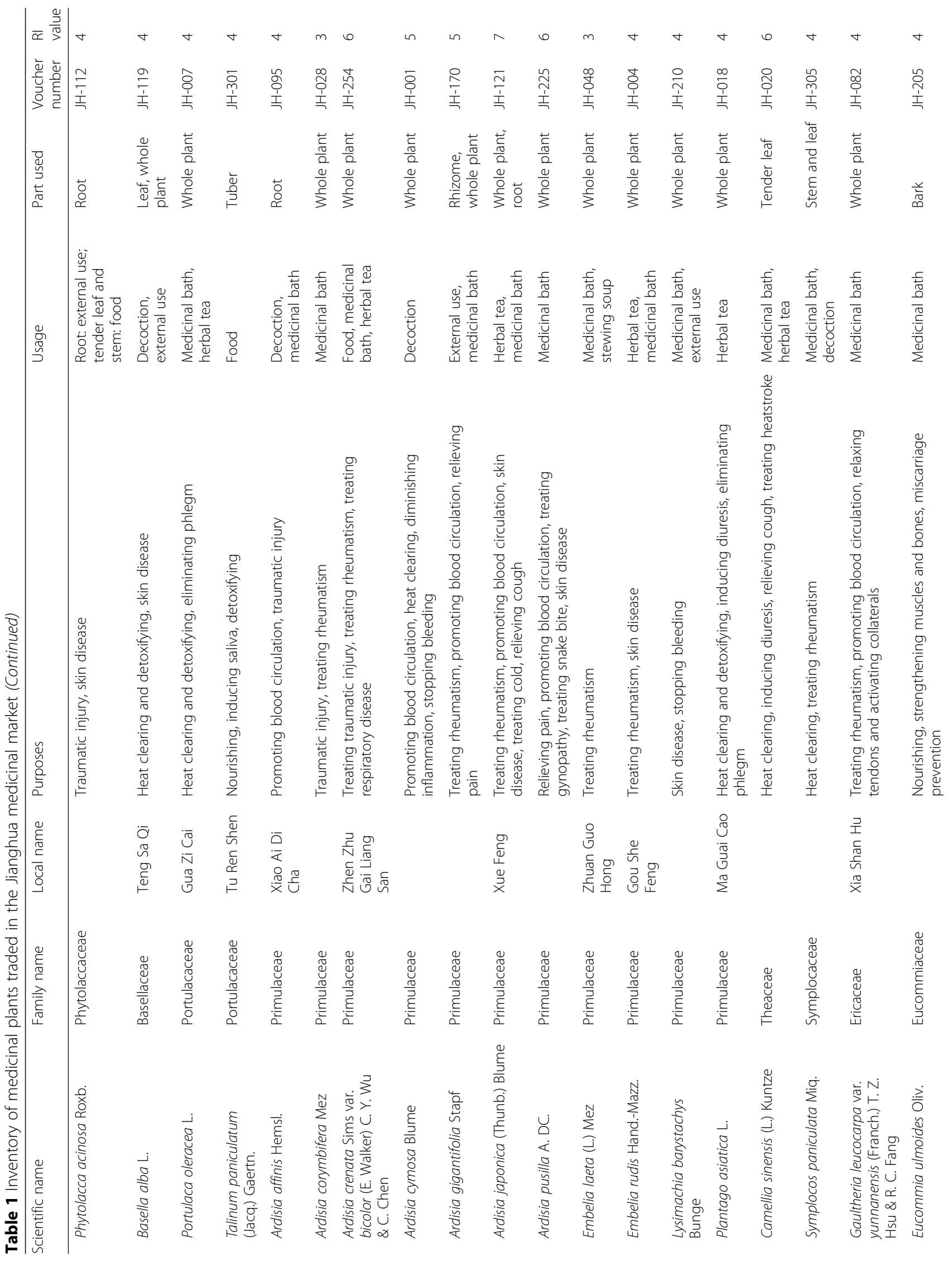




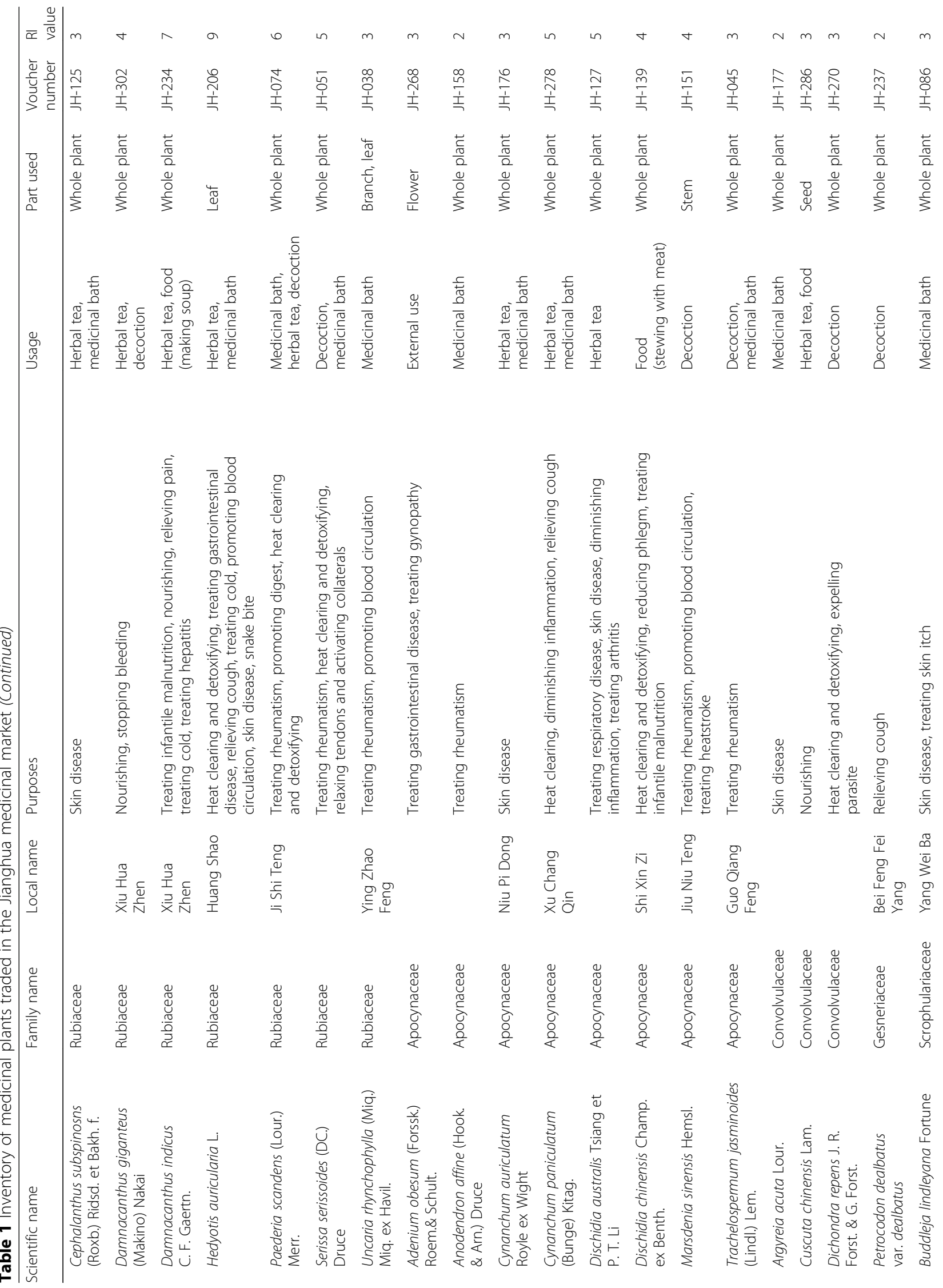




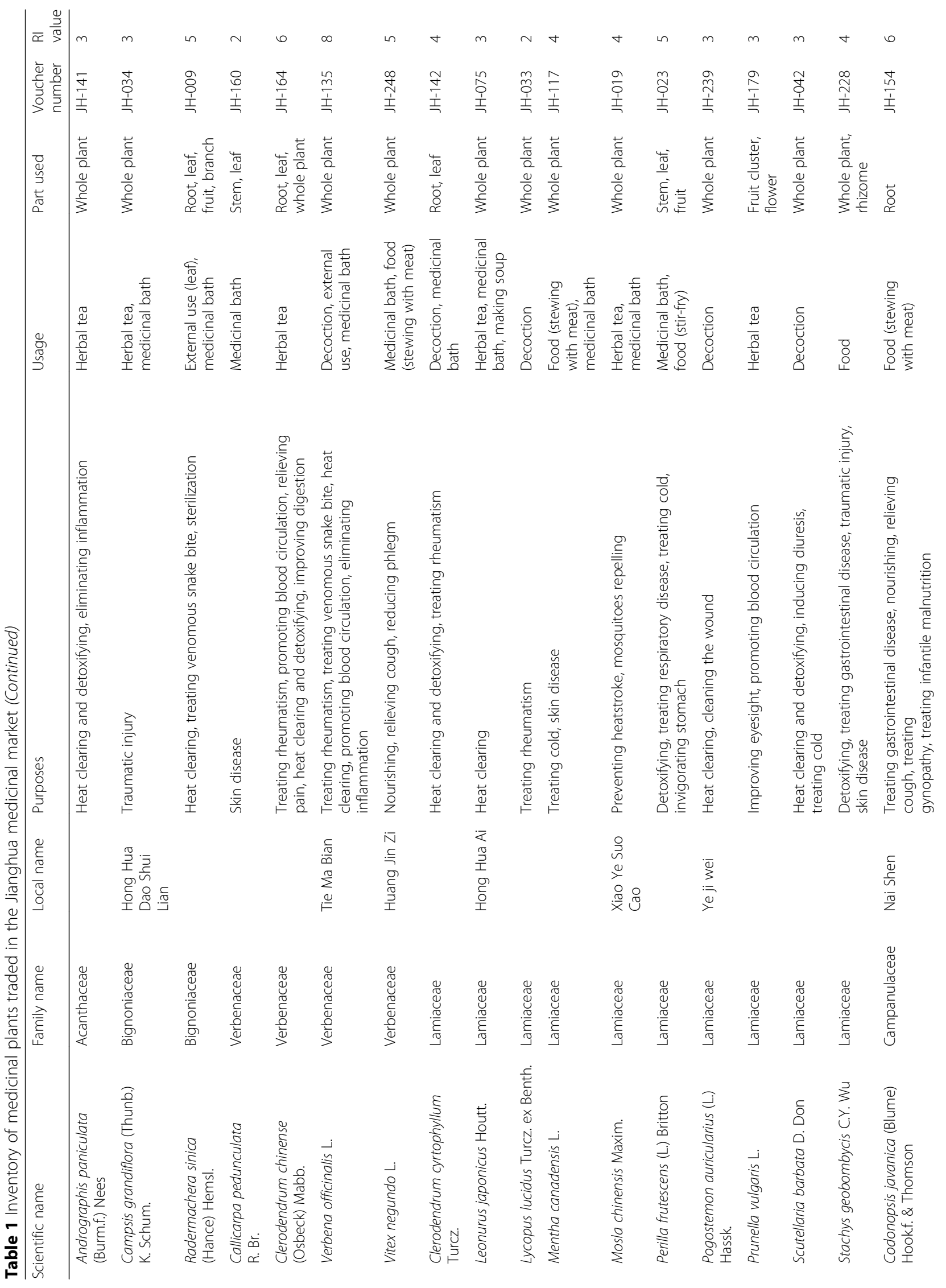




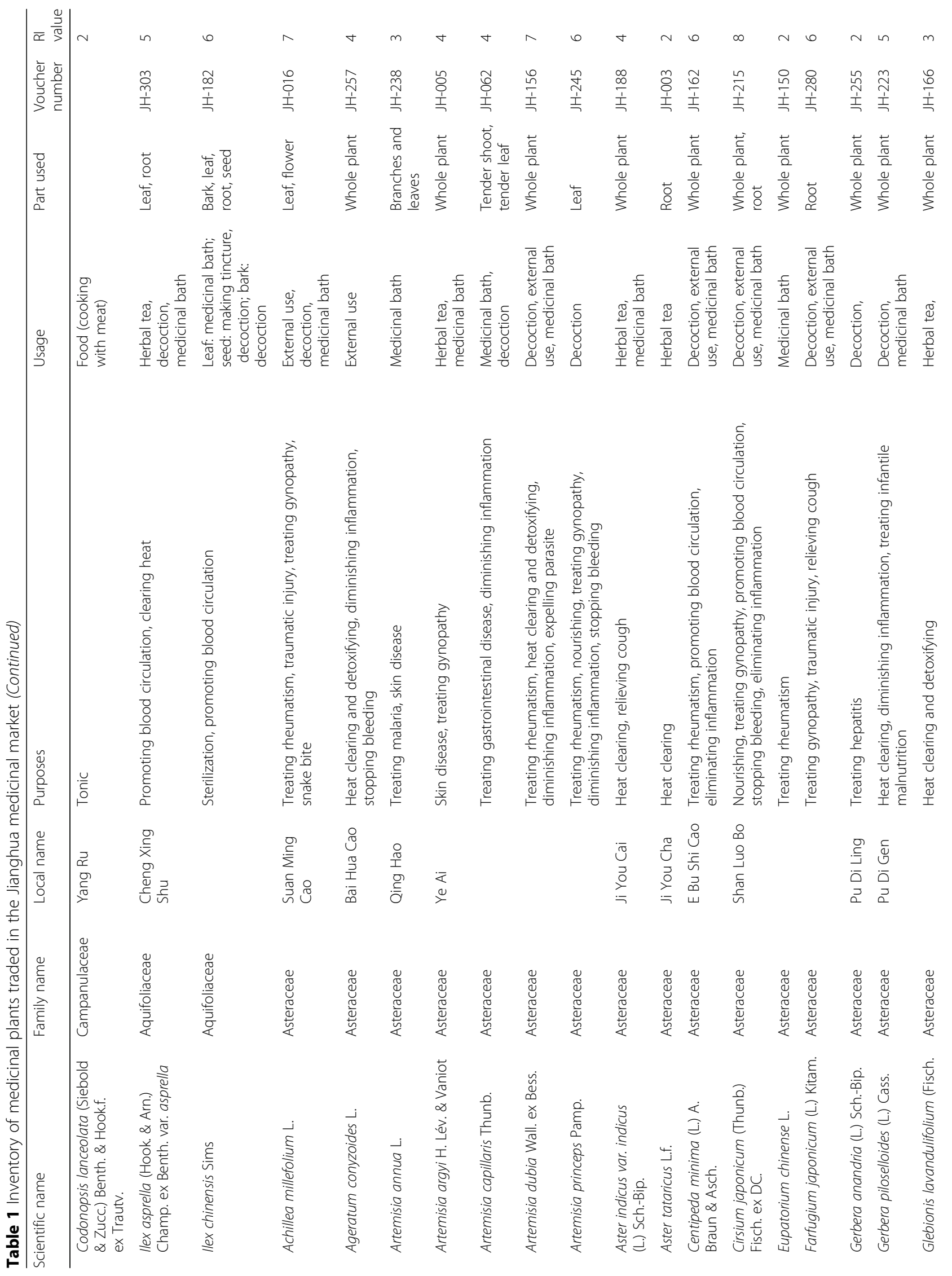




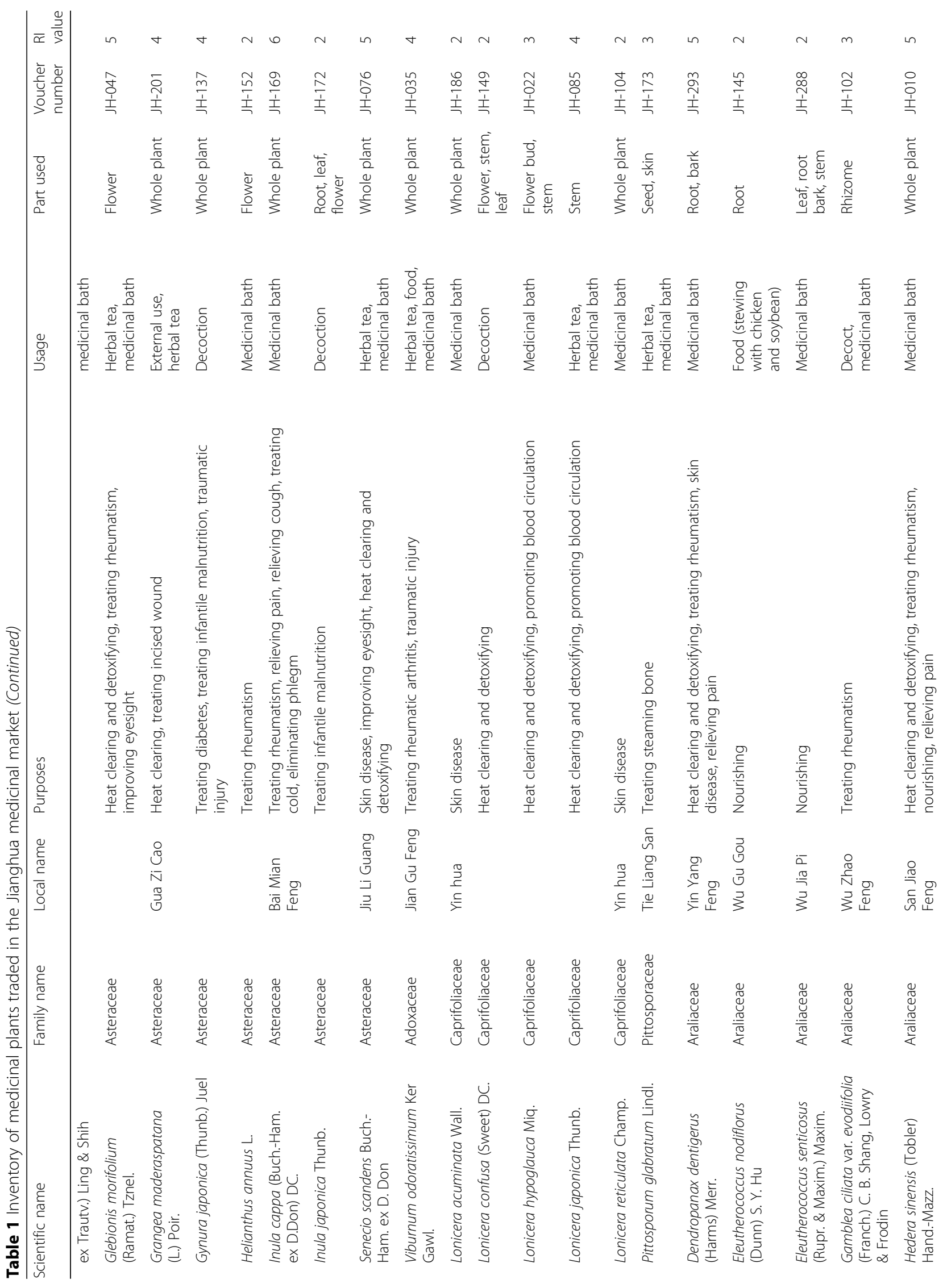




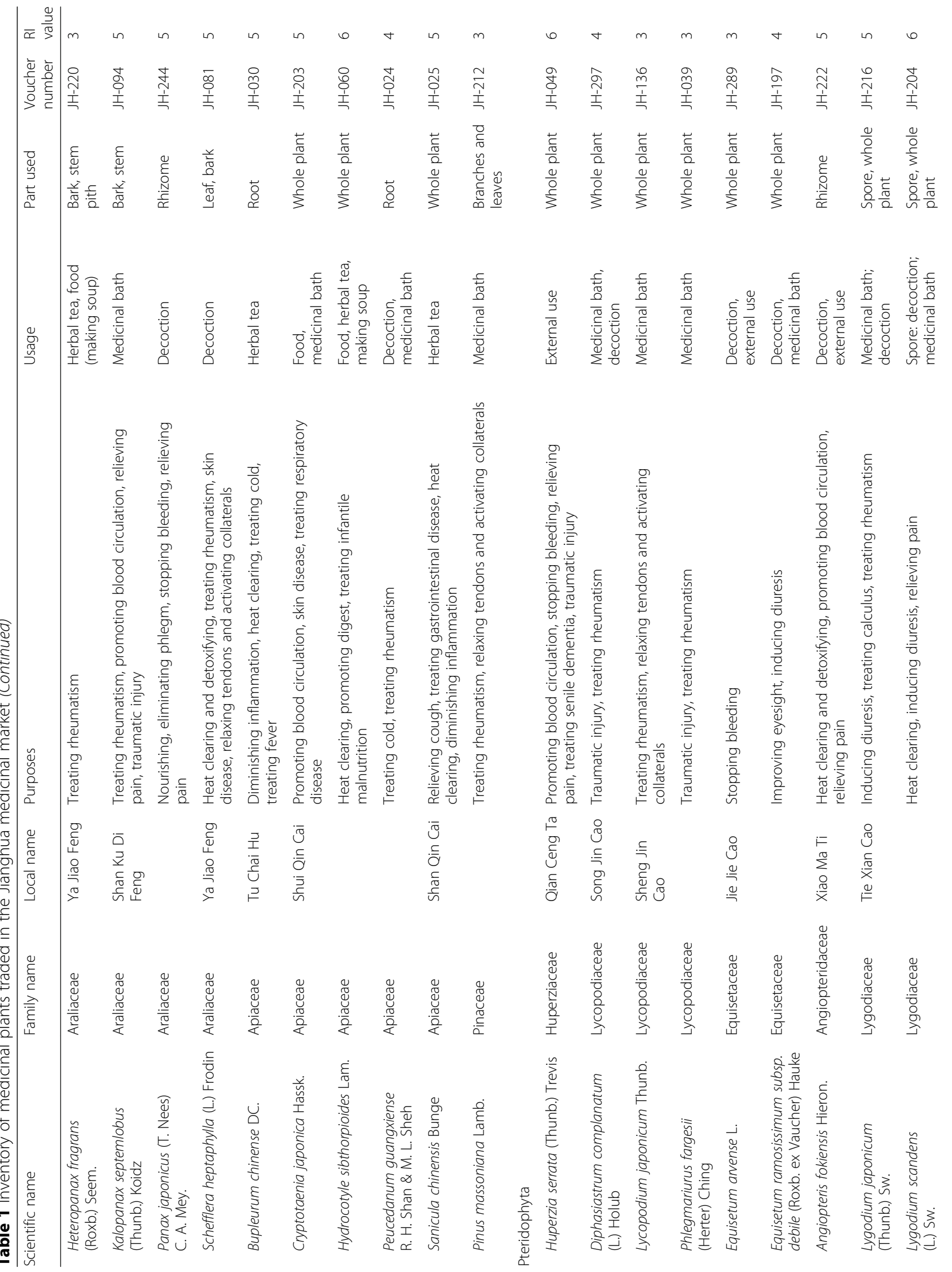




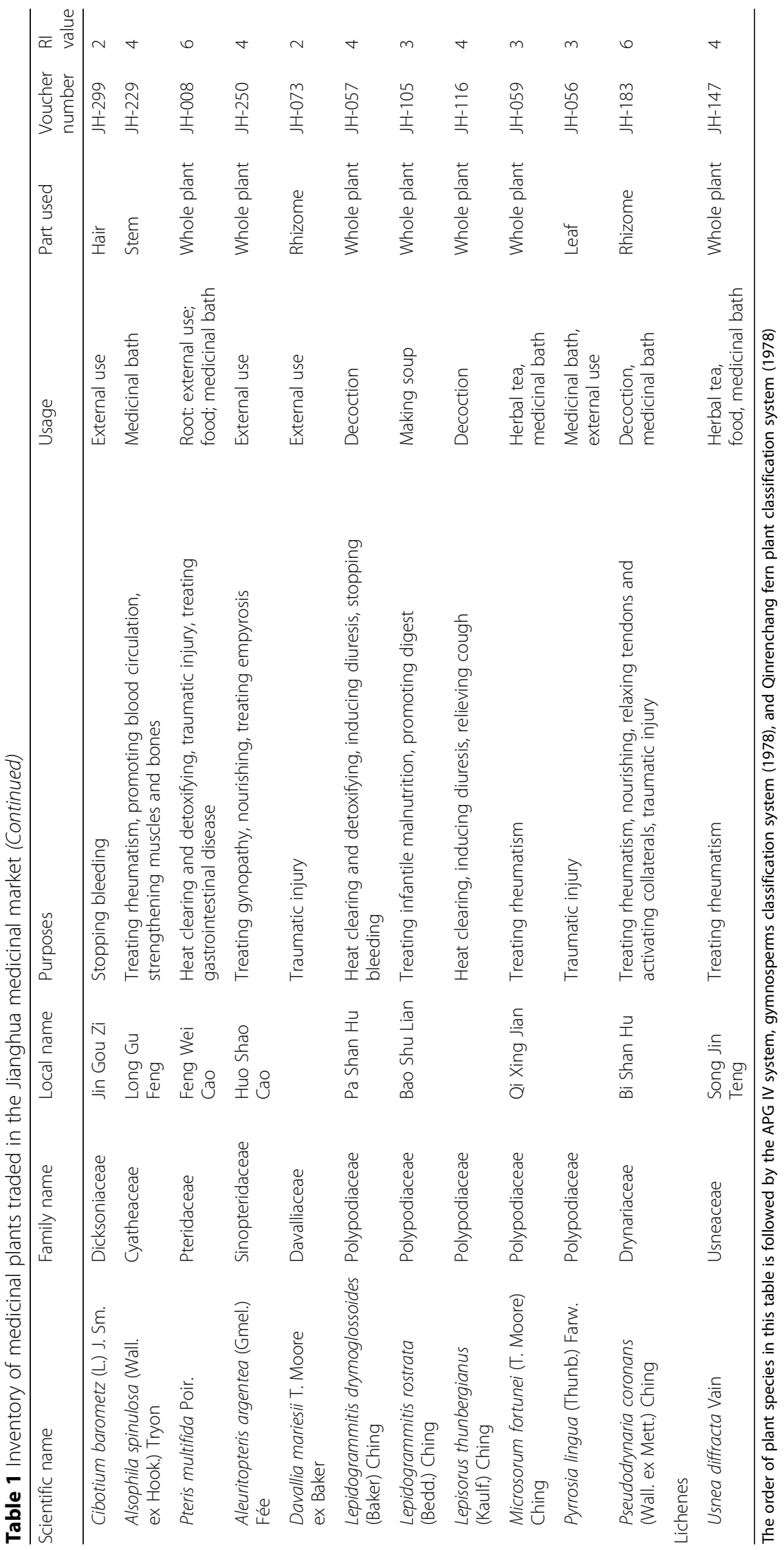


a 900-year history of clinical use in China. Some Ardisia species are common ingredients of traditional Chinese medicine formulas and Chinese folk medicines, including all the Ardisia species identified in the Jianghua medicinal market.

Compared to the previous study by Liu [15] 15 years ago, the plant species number recorded in the current study has almost tripled, which indicates that the medicinal market in Jianghua has grown considerably. This change seems to be in paradox to the loss of traditional knowledge under the impact of rapid economic development. One of the reasons for the increase in plant diversity in the marketplace might be the improved transportation and living conditions in remote areas, which makes collection easier and helps to facilitate communication among different ethnic people and thus enhances the marketplace experience. On the contrary, elder informants ( $>50$ years old) could provide Yao names (Table 1 ) to only 173 plant species (56\%). The local people used Mandarin Chinese instead of the Yao language to identify many of the medicinal plants in this survey. This phenomenon might partially reflect the gradual disappearance of the local medicine-associated knowledge. It could also be the result of merging of different medicinal culture from different groups of people. The Yao language, as a spoken language without traditional characters, can only be memorized and transmitted by humans; this might also explain the loss of local Yao language which leads to the lack of Yao names of medicinal plants.

\section{Plant parts used as medicine}

The statistics of using parts of medicinal plants traded in the market are summarized (Table 2). Using whole plants is the most frequent method with 140 species, while using roots is the second one with 67 species. Using plant leaves (48 species) and stems (33 species) are less common. Normally, the local people traded leafed branches to use in medicinal baths according to our observations. The local people prefer to use fresh medicinal plants, and thus, the aerial parts of the plants were more abundant than roots in the marketplace.

Regarding the plant parts used with their modality categories, (1) medicinal baths are the most common modality

Table 2 The used parts of medicinal plants traded in the market in Jianghua

\begin{tabular}{llllll}
\hline Plant part & Records & Percentage & Plant part & Records & Percentage \\
\hline Root & 67 & 21.9 & Fruit & 18 & 5.9 \\
Stem & 33 & 10.8 & Seed & 6 & 2.0 \\
(branches) & & & & & \\
Leaf & 48 & 15.7 & Rhizome & 27 & 8.8 \\
Stem pith & 3 & 1.0 & Bark & 14 & 4.6 \\
Flower & 14 & 4.6 & Whole & 140 & 45.8 \\
& & & plant & & \\
\hline
\end{tabular}

used by the Yao people which mostly use the leaves and the branches; (2) the reasons for using root, fruit, and flowers were quite diverse, including almost all modality categories; (3) most of the rhizomes were used for medicine, taking medicinal baths, or making herbal teas.

Most of the seeds from six species in total are edible. For example, the seeds of Ilex chinensis can be used for brewing. The seeds of some species like Cuscuta chinensis, Gleditsia sinensis, and Pittosporum glabratum can be used to make tea. The seeds of Combretum indicum, Cuscuta chinensis, and Senna tora can be cooked with other ingredients into a dish.

\section{Medicinal uses of plants}

The medicinal uses of plants traded in the market are also various, with 27 types (Table 1). The top ten therapeutic medicinal uses are listed in Table 3. These ten medicinal uses reflect the most frequent physical ailments closely attributed to local climate, environment, and the type of work [20].

Most local Yao people living in humid and highland areas are engaged in heavy physical work for a living throughout the year [15], and thus, it is not surprising that rheumatism is the number one disorder in local communities. Remarkably, almost one third of the species (106) can be used to treat rheumatism. The cold and skin diseases are also common ailments in such an environment. Herbal medicine for skin diseases and relieving cough are important and frequently used. According to traditional Yao medicinal theory, a cold and humid environment will cause the closure of pores. The heat inside the human body cannot be excreted out on time, and thus, the balance of yin and yang will be broken and cause sickness. In order to solve this problem, local people use many different herbs to clear inner heat $(33.7 \%)$ or detoxification $(26.8 \%$, relieving internal heat or fever). Moreover, it is much easier to have injuries when doing heavy physical work in mountainous environment. Herbal medicinal plants for treating

Table 3 The top ten medicinal uses of medicinal plants in the Yao marketplace in Jianghua

\begin{tabular}{llllll}
\hline $\begin{array}{l}\text { Medicinal } \\
\text { uses }\end{array}$ & Records & Percentage & $\begin{array}{l}\text { Medicinal } \\
\text { uses }\end{array}$ & Records & Percentage \\
\hline $\begin{array}{l}\text { Treating } \\
\text { rheumatism }\end{array}$ & 106 & 34.6 & Nourishing & 45 & 14.7 \\
$\begin{array}{l}\text { Clearing heat } \\
103\end{array}$ & 33.7 & $\begin{array}{l}\text { Treating } \\
\text { traumatic } \\
\text { injury }\end{array}$ & 39 & 12.8 \\
$\begin{array}{l}\text { Detoxification } \\
82\end{array}$ & 26.8 & $\begin{array}{l}\text { Relieving } \\
\text { pain }\end{array}$ & 33 & 10.8 \\
$\begin{array}{l}\text { Promoting } \\
\text { blood } \\
\text { circulation }\end{array}$ & 57 & 18.6 & $\begin{array}{l}\text { Relieving } \\
\text { cough }\end{array}$ & 33 & 10.8 \\
$\begin{array}{l}\text { Treating skin } \\
\text { diseases }\end{array}$ & 45 & 14.7 & $\begin{array}{l}\text { Stopping } \\
\text { bleeding }\end{array}$ & 26 & 8.5 \\
\hline
\end{tabular}


traumatic injury, relieving pain, and stopping bleeding comprise a large part of the medicinal market. Herbs for nourishing and promoting blood circulation also comprise a large part of the market because they can effectively help local people to recover from injuries.

Yao medicine is renowned for being good at treating rheumatism and gynecological diseases [21]. One of our former studies found that red-headed Yao women like to use herbs like Aeschynanthus bracteatus, Celosia argentea, and Sabia fasciculata to make decoctions for medicinal baths so that they can return to farming work as soon as a week after giving birth [22]. Those herbs are believed to have very good anti-inflammatory and tonic effectiveness by local people. In the present study, no medicinal plant was mentioned for postpartum recovery or gynecological diseases by local people. Most of the herbs for nourishment or pain relief like Amomum villosum, Anemarrhena asphodeloides, Vitex negundo, and Saururus chinensis are regarded to be good for women according to local people.

\section{Modalities of medicinal plants}

Eight categories of modalities of medicinal plants about the market were recorded. About $60 \%$ of plant species were used for medicinal baths, making it the most common traditional medicinal modality. Medicinal baths are a characteristic custom for the Yao ethnic group. When having a medicinal bath, the skin, as the largest human organ, can be fully exposed to the medicinal bath water so that certain medicinally useful molecules can be absorbed that way [23, 24]. The heat of the water can also stimulate the blood capillaries and lymph vessels to expand and promote blood circulation and metabolism [23, 24]. There are many aromatic plants used in medicinal baths like Gaultheria leucocarpa var. yunnanensis. The heat of the bath water can accelerate the volatile molecules to evaporate from medicinal plants, which can be absorbed by breathing and also strengthen the effectiveness of medicine [4].

Based on our investigation, one or more species of medicinal plants are typically immersed in hot water for bathing. The Yao people do not have settled formulas and precise amounts of medicinal plants for these baths. They usually put the plants with similar pharmacological efficacy together to enhance their effects. These Yao formulas have not been well studied scientifically, and side effects are not well documented. Therefore, further phytochemical, pharmacological, and clinical tests are needed to determine the safety and efficacy of these traditional practices [4].

Besides medicinal baths, other modality categories of medicinal plants include decoctions, teas, food and spices, tinctures, crushed or burnt, and externally applied. Decoctions are the second most common modality category (Table 4) with 106 species (34.6\%). It is also one of the most common ways that traditional Chinese medicines
Table 4 The modality of medicinal plants in the market in Jianghua

\begin{tabular}{llllll}
\hline Modality & Records & Percentage & Modality & Records & Percentage \\
\hline $\begin{array}{l}\text { Medicinal } \\
\text { bath }\end{array}$ & 179 & 58.5 & $\begin{array}{l}\text { External } \\
\text { use }\end{array}$ & 36 & 11.8 \\
Decoction & 106 & 34.6 & Tincture & 11 & 3.6 \\
Tea & 79 & 25.8 & Spice & 2 & - \\
Food & 44 & 14.4 & Burnt & 1 & - \\
\hline
\end{tabular}

are used. People usually use water to decoct the medicinal plant for a long time and finally take the decoction to treat certain illnesses. Making herbal tea and cooking is the third (79 spp., 25.8\%) and fourth (44 spp., 14.4\%) processing methods, respectively. It is noteworthy that the great majority of medicinal plants for food are used for infant malnutrition. More than $10 \%$ of the medicinal species are externally applied which is mostly for treating traumatic injuries. Local people usually crush these herbs and put on the wound to stop bleeding, diminish inflammation, relieve pain, and accelerate recovery.

Seeds of Gleditsia sinensis can be used incinerated to treat skin diseases like itching (it can also be used by decoction and medicinal bath). Several studies revealed that the chemical constituents extracted from Gleditsia sinensis showed good anti-bacterial, anti-allergy, anti-inflammatory, and anti-proliferative bioactivities [25-27]. The incineration process is unique: the local people typically use a flame to burn the Gleditsia sinensis seeds. Then, they hold a steel knife and make sure the blade is on the top of both the flame and the seeds to collect the soot, and it will be scraped off the blade and painted on the afflicted part of the patient. Besides the Yao people in Hunan Province, the Dong people in Guangxi Region also use this incineration method to treat illnesses. According to our previous study on the medicinal market in Guangxi Province (unpublished), the Dong people use the same method to incinerate certain poisonous plants like the root of Alangium chinense, the whole herb of Macleaya cordata, and the root of Tripterygium wilfordii. This method is thought to detoxify these poisonous plants, according to some Dong practitioners.

\section{Frequency of occurrence and $R I$ index of some medicinal plants}

The frequency of occurrence of each medicinal herb was recorded. This frequency signifies how many stalls sold a particular medicinal plant species. Some plant species were more frequently found than others (Fig. 2). Most species are used for clearing the inner heat and treating rheumatism. These results (Fig. 2) suggest that (1) the plants are widely distributed in local habitats and may be relatively easier to access; (2) the plants may have comparatively better effectiveness than the others so that they 


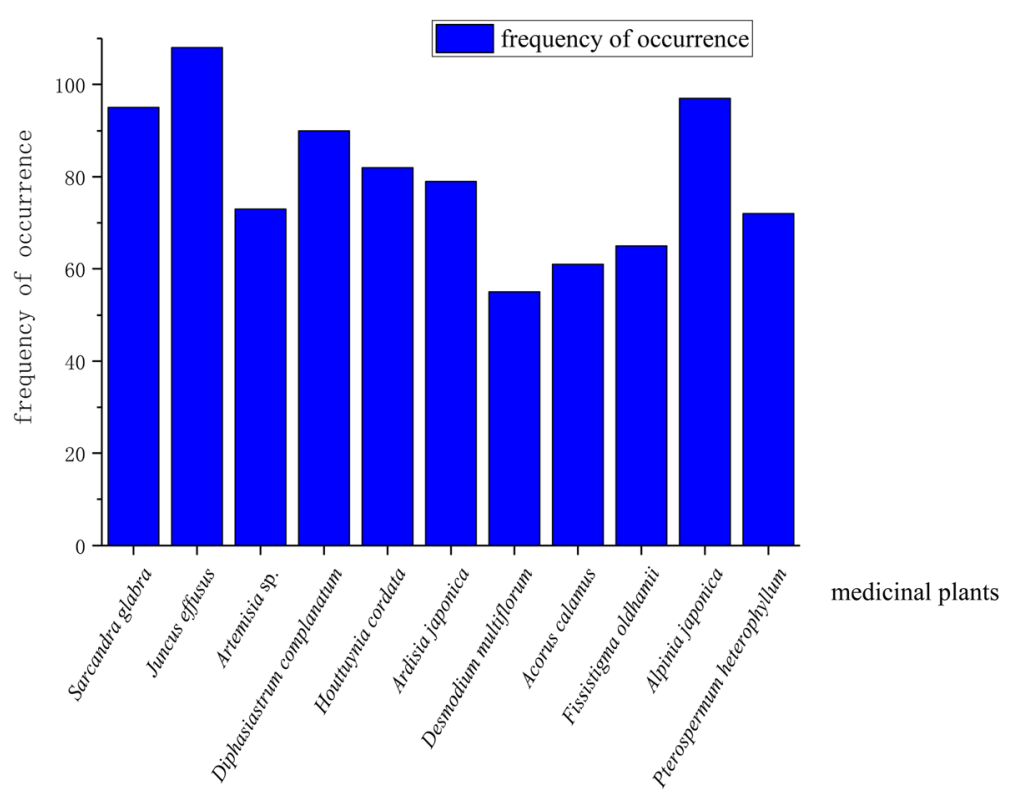

Fig. 2 The frequency of occurrence of some medicinal plants in Jianghua County

are more popular among local communities; and (3) inner heat and rheumatism are common problems for local people confirming the result from Table 3. High demands for those herbs and their effectiveness might be the major reasons leading to the high frequency of occurrence about the medicinal market.

The relative importance index is used to reflect the comprehensive utilization value [19]. The species with RI index greater than 0.4 are listed in Table 5. The modality types of these species are more various than other species. Most of them are edible and may be cooked as food and made into herbal tea or medicinal tincture. This character of being both edible and therapeutic indicated that these plants (Table 5) might be safer to humans with fewer side effects. Another reason for the relatively high RI index is that those species are easily acquired in local habitats and thereby make them more. The species themselves are locally widespread. For example, Hedyotis auricularia, Cirsium japonicum, and Verbena officinalis can be easily found on the roadsides

Table 5 The medicinal plants with higher Rl

\begin{tabular}{|c|c|c|c|}
\hline Name & Medicinal effectiveness type & Modalities & $\mathrm{Rl}$ \\
\hline Cirsium japonicum (Thunb.) Fisch. ex DC. & $\begin{array}{l}\text { Nourishing, treating gynopathy, promoting blood } \\
\text { circulation, stopping bleeding, eliminating inflammation }\end{array}$ & $\begin{array}{l}\text { Decoction, external use, } \\
\text { medicinal bath }\end{array}$ & 0.49 \\
\hline Verbena officinalis L. & $\begin{array}{l}\text { Treating rheumatism, treating venomous snake bite, heat } \\
\text { clearing, promoting blood circulation, } \\
\text { eliminating inflammation }\end{array}$ & $\begin{array}{l}\text { Decoction, external use, } \\
\text { medicinal bath }\end{array}$ & 0.49 \\
\hline Achillea millefolium L. & $\begin{array}{l}\text { Treating rheumatism, traumatic injury, treating gynopathy, } \\
\text { snake bite }\end{array}$ & $\begin{array}{l}\text { External use; decoction } \\
\text { water; medicinal bath }\end{array}$ & 0.47 \\
\hline $\begin{array}{l}\text { Rotala rotundifolia (Buch.-Ham. ex Roxb.) } \\
\text { Koehne }\end{array}$ & Heat clearing, traumatic injury, treating snake bite, skin disease & $\begin{array}{l}\text { Decoction, external use, } \\
\text { medicinal bath }\end{array}$ & 0.47 \\
\hline Pterospermum heterophyllum Hance & $\begin{array}{l}\text { Treating rheumatism, relaxing tendons and activating collaterals, } \\
\text { relieving pain, treating arthritis, }\end{array}$ & $\begin{array}{l}\text { Herbal tea, medicinal bath, } \\
\text { food (stew with chicken) }\end{array}$ & 0.47 \\
\hline Agrimonia pilosa Ledeb & $\begin{array}{l}\text { Treating gastrointestinal disease, diminishing inflammation, } \\
\text { stopping bleeding, treating heatstroke }\end{array}$ & $\begin{array}{l}\text { Medicinal bath, medicine, } \\
\text { herbal tea }\end{array}$ & 0.47 \\
\hline Artemisia dubia Wall. ex Bess. & $\begin{array}{l}\text { Treating rheumatism, heat clearing and detoxifying, } \\
\text { diminishing inflammation, expelling parasite }\end{array}$ & $\begin{array}{l}\text { Decoction, external use, } \\
\text { medicinal bath }\end{array}$ & 0.47 \\
\hline Hedyotis auricularia L. & $\begin{array}{l}\text { Heat clearing and detoxifying, treating gastrointestinal } \\
\text { disease, relieving cough, treating cold, promoting blood } \\
\text { circulation, skin disease, snake bite }\end{array}$ & Herbal tea, medicinal bath & 0.40 \\
\hline Achillea millefolium L. & $\begin{array}{l}\text { Treating rheumatism, traumatic injury, treating gynopathy, snake } \\
\text { bite }\end{array}$ & $\begin{array}{l}\text { External use, decoction } \\
\text { water, medicinal bath }\end{array}$ & 0.47 \\
\hline
\end{tabular}


and in the fields. Gleditsia sinensis, Damnacanthus indicus, and Ardisia japonica often appear in both wild and home gardens according to our observations. According to our interviews, almost everyone, including both vendors and local residents, can distinguish these species (Table 5). These species listed in Table 5 have high value in use with good potential for future development.

\section{Demographics of vendors}

Most vendors are Yao mountain people, and they can access many wild medicinal plants easily. However, in most cases, only elder vendors can speak the Yao language while the younger generation only speaks Mandarin Chinese or other local dialects because of the education and cultural fusion brought by the rapidly changing society and vigorous construction in the rural area. The age and gender of vendors have been recorded and analyzed (Table 6). The age range for vendors was 22-83 years old. The number of vendors older than 50 years old accounts for about $70 \%$ among all vendors. Those between 50 and 59 are the most with $90(32.6 \%)$ people. The age composition for all vendors is slightly aging, but there are still many younger vendors, especially in 30-49 years old. Vendors younger than 30 years old are only 12 people (4.4\%). This age composition reflects the succession problem of local traditional knowledge of Yao medicinal plants.

As for the gender structure of the vendors, the number of men and women older than 50 years old is about equal. But under 50 years old, the number of men is twice the number of women. It is probably because that women dedicate themselves to housework, childcare, keeping livestock, and farmyard management while the men more commonly collect wild medicinal herbs in the high mountains. The interviews with the young vendors also showed that collecting the wild medicinal plants and selling them were considered only a temporary job. Much of the work collecting plants is done by the older generation and sold by the youngers who have other steady jobs. It was also found that the medicinal plants sold by elder vendors generally showed more botanical diversity but were gathered in relatively smaller amounts, while the plants sold by younger vendors were less diverse botanically but in larger amounts. These differences indicated that elder vendors master more traditional medicinal knowledge than younger vendors

Table 6 The demographics of vendors

\begin{tabular}{llllllllllllllllll}
\hline & $20-29$ & $30-39$ & $40-49$ & $50-59$ & $60-69$ & $70-79$ & $>80$ & Total \\
A & $M$ & W & M & W & M & W & M & W & M & W & M & W & M & W & \\
B & 8 & 4 & 20 & 8 & 24 & 14 & 44 & 46 & 16 & 28 & 32 & 32 & 0 & 2 & 276 \\
C & 12 & & 28 & & 36 & & 90 & & 44 & 64 & 2 & 276 \\
D & 4.35 & 10.14 & 13.04 & 32.61 & 15.94 & 23.19 & 0.73 & $100 \%$ \\
\hline
\end{tabular}

$A$ ganders, $B$ number of people, $C$ number of people in different age groups, $D$ percentages while younger vendors have more energy to search larger areas to collect larger amounts of wild medicinal plants. All these research findings suggest that the local traditional Yao medicine-associated knowledge is gradually decreasing.

The medicinal market in the Dragon Boat Festival in Jianghua is in a relatively large-scale venue with 269 stalls or vendors according to our investigations. Such a big traditional medicinal market appears at present time with well-developed Western medicine indicating that local people have a rich traditional knowledge of herbal medicine and depend upon it. However, most of the medicinal plants are not expensive, and the profit margin is slim. The fact that the vendors are still willing to come even if it is hard to collect the plants and time consuming suggests that they believe this is not only just for obtaining income but also following their tradition and even a way to celebrate the birthday of the Yao Medicinal Lord. As for the buyers, almost everyone in each age group knows a lot about medicinal plants. It demonstrates that the traditional knowledge of medicinal plants is widespread in the Yao community. The speed of the disappearance of related traditional knowledge gets much slower which is closely due to the medicinal markets in festival days which have played a great role of knowledge sharing in local community.

\section{Conservation of Yao medicinal knowledge}

The traditional knowledge of Yao medicine is apparently decreasing. For instance, local people only have medicinal baths on the important festivals including the Dragon Boat Festival, the Double Ninth Festival, and the Panwang Festival nowadays. But they used to take a medicinal bath once a day in the past, according to local people. Less frequent practices will partially make it harder to keep such knowledge. The demographics of vendors and the incomplete vernacular names of medicinal plants also reflected this truth on other aspects. Even though a modern writing system of Yao language has been created, most of the Yao people in Jianghua still prefer spoken tradition since they receive Mandarin education beginning in primary school. The lack of a widely adopted writing system of the Yao language is a vulnerability for knowledge transfer [28].

As for the conservation of Jianghua traditional medicinal knowledge, the biggest challenge is apparently the shortage of professional personnel. One problem is that the Yao youth do not know enough about traditional Yao medicine and they are not confident about it [16]. By the impact of modern Western medicine, some local people prefer to use faster and more precise methods instead of their own traditional practices [29]. In addition, although the old masters of Yao medicine are dying out, the young people are not willing to study it or make it as a livelihood because it is not enough for feeding the family [15]. Nowadays, the Chinese government has recognized ethnomedicine and published a series of policies to support their 
protection and development after the foundation of the whole country [30,31]. However, it is still urgent to cultivate more professional talents in the field of ethnomedicine by issuing more preferential policies and funds. It is necessary and helpful to normalize Yao doctors, to systemize the Yao medicinal theory, and to publish accompanying textbooks as well as other academic books.

The conservation of local medicinal plant resources is also quite important especially the conservation of rare and endangered plant species. The maintaining of the biodiversity is the material insurance for the development of relative traditional knowledge. Some endangered plant species were observed being traded about the Jianghua medicinal market like Cibotium barometz, Alsophila spinulosa, Dendrobium officinale, and Semiliquidambar cathayensis [32]. The stem and bark area of Semiliquidambar cathayensis is a very popular and effective traditional medicine for rheumatism locally. According to our surveys, the trading volume of Semiliquidambar cathayensis stem is large, and this plant material was all collected from the wild. Large-scale collection of plant resources will damage the local biodiversity and finally affect the stability of the local ecosystem.

The medicinal market in the Dragon Boat Festival in Jianghua County is a significant cultural event. Using its fame to develop tourism and attract businesses and investment may bring considerable money, but extreme care must be taken not to do any harm to local biodiversity and cultural diversity [33, 34].

In such a beneficial environment with the support by the government, it is an opportunity for local government agencies to improve better development of the medicinal market. Based on this investigation and others, the local government should consider protecting and developing the medicinal market to provide a better environment for vendors and buyers. The training of young personnel will strongly support the sustainable development of Yao medicine. In the meanwhile, the local government can also support the practitioners to exploit related by-products and apply for patents, even combining with poverty alleviation. Additionally, the local biodiversity and biological resources especially some endangered species should be protected by issuing conservation regulations or laws and by popularizing the green and sustainable awareness among local people.

\section{Conclusion}

The herbal medicinal market is an important traditional activity celebrating the Dragon Boat Festival in Jianghua County, China. The formation and development of this special market is not only closely involved with local social history, but also local natural environment. As an herb trading site, this market plays an important role in the local community for medicinal knowledge exchange and heritage.

The result of our study showed the rich taxonomic diversity of medicinal plants and the diversity of their medicinal parts, medicinal uses, and modality categories. Based on our investigations, 306 species (belonging to 113 families and 249 genera) were recorded. The taxonomic distribution of those medicinal herbs clearly demonstrates the taxonomic diversity of the marketplaces. The whole plants have been used most frequently. Treating rheumatism and clearing inner heat are the most frequent symptoms addressed by these local healers. Medicinal baths are a special tradition in Jianghua County and account for the most common modality of the medicinal herbs. It is important to use modern scientific methods to verify the safety and efficacy of these traditional practices.

Although our analysis of the vendors reflected the predicament of losing traditional knowledge, some results are still promising like the species richness at the medicinal market, the local popularity of medicinal plant use, and the positive attitude to the traditional Yao medicine by local youths. These positive phenomena are associated with the medicinal market in some level, and it might provide a valuable reference for other places to sustainably develop local traditional medicine. The cultivation of relevant talents and maintaining the local biodiversity may be viable solutions to further develop traditional Yao medicine in Jianghua. Based on this investigation, and taking modern Yao culture into consideration, some proposals for improved construction, the protection of the medicinal market on the Dragon Boat Festival, and the traditional medicinal knowledge have been made.

\section{Acknowledgements}

We are very grateful to the local people in Jianghua County, Hunan Province, who have provided valuable information about the medicinal plants in the medicinal market.

\section{Funding}

This work was supported by the Key Laboratory of Ethnomedicine (Minzu University of China) of the Ministry of Education of China (KLEM-ZZ201806), National Natural Science Foundation of China (31870316, 31761143001, and 31161140345), Minzu University of China (Collaborative Innovation Center for Ethnic Minority Development and YLDXXK201819), and Ministry of Education of China and State Administration of Foreign Experts Affairs of China (B08044).

\section{Availability of data and materials}

All data generated or analyzed during this study are included in this published article and its supplementary information files.

\section{Authors' contributions}

$L C L$ conceived of and designed the study. $L C L, L Y J, L B, L B S, L S Z, Z B X, L C R$, $L Y$, and GZY conducted data collection. LBS and ZLH integrated the inventory and its analysis. LCL, LCR, LY, and LB identified the plants. LBS and LYJ wrote the manuscript. EJK edited the English and provided helpful comments as well. All authors read and approved the final manuscript.

Ethics approval and consent to participate Not applicable. 


\section{Consent for publication}

Not applicable.

\section{Competing interests}

The authors declare that they have no competing interests.

\section{Publisher's Note}

Springer Nature remains neutral with regard to jurisdictional claims in published maps and institutional affiliations.

\begin{abstract}
Author details
${ }^{1}$ Key Laboratory of Ethnomedicine (Minzu University of China), Ministry of Education, Beijing 100081, China. ${ }^{2}$ College of Life and Environmental Sciences, Minzu University of China, Beijing 100081, China. ${ }^{3}$ Key Laboratory of Modern Agricultural Equipment and Technology, Ministry of Education, Jiangsu University, Zhenjiang 212013, Jiangsu, China. ${ }^{4}$ Guangxi Institute of Botany, Guangxi Region and Chinese Academy of Sciences, Guilin 541006, China. ${ }^{5}$ Lehman College, City University of New York, Bronx, New York 10468, USA. ${ }^{6}$ Kunming Institute of Botany, Chinese Academy of Sciences, Kunming 650201, China.
\end{abstract}

Received: 9 May 2018 Accepted: 12 September 2018 Published online: 17 October 2018

\section{References}

1. Zhang ZY. A brief account of traditional Chinese festival customs. J Pop Cult. 1993; https://doi.org/10.1111/j.0022-3840.1993.1354684.x.

2. $\quad$ Yang $C Y$, Long $C L$, Shi YN, Wang $Y H$, Wang HS. Ethnobotanical study on medicinal market during Dragon Boat Festival in Jingxi county, southwestern Guangxi region. J CUN (Nat Sci Edit). 2009;18:16-26.

3. Williams V. Trade and socio-economic value of forest and woodland resources within the medicinal plant market in Johannesburg. Pietermaritzburg: University of KwaZulu-Natal Press; 2004.

4. Li R, Long CL. Studies on Yao ethnomedicine in Jinping of Yunnan. Chin Pharm J. 2000;35:775-9.

5. Balunas MJ, Kinghorn AD. Drug discovery from medicinal plants. Life Sci. 2005; https://doi.org/10.1016/j.lfs.2005.09.012.

6. Normile D. Asian medicine, the new face of traditional Chinese medicine. Science. 2003. https://doi.org/10.1126/science.299.5604.188.

7. Pei SJ. Ethnobotanical approaches of traditional medicine studies: some experiences from Asia. Pharm Biol. 2001; https://doi.org/10.1076/phbi.39. s1.74.0005.

8. Zhang D, Duan L, Zhou N. Market survey on traditional medicine of the Third Month Fair in Dali Prefecture in Yunnan Province, Southwest China. Afr J Tradit Complem. 2014; https://doi.org/10.4314/ajtcam.v11i2.25.

9. Han JP, Pang XH, Liao BS, Yao H, Song JY, Chen SL. An authenticity survey of herbal medicines from markets in China using DNA barcoding. Sci Rep. 2016; https://doi.org/10.1038/srep18723.

10. Lee S, Xiao CJ, Pei SJ. Ethnobotanical survey of medicinal plants at periodic markets of Honghe Prefecture in Yunnan Province, SW China. J Ethnopharmacol. 2008; https://doi.org/10.1016/j.jep.2008.02.001.

11. Hong LY, Wang Y, Li JQ, Lei QY, Zhou JJ, Qin L, Long CL. Medicinal plants traded in traditional markets of southern part of Guizhou, Southwest China. Planta Med. 2016; https://doi.org/10.1055/s-0036-1596597.

12. Lin CR, Liu Y, Xu WB, Liang YY. The diversity of medicinal plant resources in traditional medicinal market in Jingxi County, Guangxi, China. Lishizhen Med Mater Medica Res. 2010;21:3286-8.

13. Zhao YY. The plant resources in the medicinal market on the Dragon Boat Festival in Yongzhou, China. Chin Wild Plant Resour. 2006;25:27-8.

14. Dai B, Qiu CC. Preliminary report of the investigation of medicinal plants on medicinal market during Dragon Boat Festival in Gongcheng Yao Autonomous County of Guangxi. J Chin Med Mater. 1995;18:334-9.

15. Liu YH. The research on Yao ethnic medicine in Hunan Province, China. Changsha: Hunan Science and Technology Press; 2002.

16. Yin X, Liu YP, Tang CM, Feng L. The investigation on the current situation and problems of the inheritance and development of Yao medicine in Jianghua. Pioneering Sci Technol Mon. 2016;29:11-3.

17. Li XH. The annals of Jianghua Yao Autonomous County. Beijing: Ethnic Publishing House; 2005.
18. Bennett BC, Prance GT. Introduced plants in the indigenous Pharmacopoeia of Northern South America. Econ Bot. 2000; https://doi.org/10.1007/ BF02866603.

19. Albuquerque UP, Lucena RFP, Monteiro JM, Florentino ATN, Almeida CCBR. Evaluating two quantitative ethnobotanical techniques. Ethnobot Res Appl. 2006; https://doi.org/10.17348/era.4.0.51-60.

20. Yineger $\mathrm{H}$, Yewhalaw D. Traditional medicinal plant knowledge and use by local healers in Sekoru District, Jimma Zone, Southwestern Ethiopia. J Ethnobiol Ethnomed. 2007; https://doi.org/10.1186/1746-4269-3-24.

21. Long CL, Li R. Ethnobotanical studies on medicinal plants used by the redheaded Yao people in Jinping, Yunnan Province, China. J Ethnopharmacol. 2004; https://doi.org/10.1016/j.jep.2003.10.021.

22. Li S, Long CL, Liu F, Lee S, Guo Q, Li R, Liu Y. Herbs for medicinal baths among the traditional Yao communities of China. J Ethnopharmacol. 2006; https://doi.org/10.1016/j.jep.2006.04.014.

23. Van-Tubergen A, Van-der-Linden S. A brief history of spa therapy. Ann Rheum Dis. 2002; https://doi.org/10.1136/ard.61.3.273.

24. Wang J, Zhu M, Xiang L, Xiao Y. Chinese medicinal bath for psoriasis vulgaris. J Chin Phys. 2002;4:96-7.

25. Zhou LG, Li D, Wang JG, Liu YS, Wu JY. Antibacterial phenolic compounds from the spines of Gleditsia sinensis Lam. Nat Prod Res. 2007; https://doi.org/ 10.1080/14786410701192637.

26. Dai Y, Chan YP, Chu LM, But PP. Antiallergic and anti-inflammatory properties of the ethanolic extract from Gleditsia sinensis. Biol Pharm Bull. 2002; https://doi.org/10.1248/bpb.25.1179.

27. Chow LM, Tang JC, Teo IT, Chui CH, Lau FY, Leung TW, Cheng G, Wong RS, Wong IL, Tsang KM, et al. Antiproliferative activity of the extract of Gleditsia sinensis fruit on human solid tumour cell lines. Chemotherapy. 2002; https:// doi.org/10.1159/000069713.

28. Escobar A. Whose knowledge, whose nature? Biodiversity, conservation, and the political ecology of social movements. J Polit Ecol. 1998;5:53-82.

29. Burke A, Wong YY, Clayson Z. Traditional medicine in China today: implications for indigenous health systems in a modern world. Am J Public Health. 2003;93:1082-4.

30. Dai B, Qiu CC. The general development situation and prospect of Chinese national medicine. Chin J Ethnomed Ethnopharm. 2005;72:1-4.

31. Zhu BG. The significance to protect Chinese national medicine as an intangible cultural heritage. Chin J Ethnomed Ethnopharm. 2007;13:1-4.

32. Ministry of Environmental Protection, Chinese Academy of Sciences. Red list of China's biodiversity: higher plants. 2013. http://www.mee.gov.cn/gkml/ hbb/bgg/201309/W020130917614244055331.pdf

33. Zhou YJ, Zhang XH, Ji XP, Ji XL, Li LP, Yong FS, Chen GQ. Development and utilization of Huili drug market from perspective of cultural tourism. Mod Chin Med. 2017:19:287-9.

34. Phuthego T, Chanda R. Traditional ecological knowledge and communitybased natural resource management: lessons from a Botswana wildlife management area. Appl Geogr. 2004; https://doi.org/10.1016/j.apgeog.2003. 10.001

Ready to submit your research? Choose BMC and benefit from:

- fast, convenient online submission

- thorough peer review by experienced researchers in your field

- rapid publication on acceptance

- support for research data, including large and complex data types

- gold Open Access which fosters wider collaboration and increased citations

- maximum visibility for your research: over $100 \mathrm{M}$ website views per year

At $\mathrm{BMC}$, research is always in progress.

Learn more biomedcentral.com/submissions 